
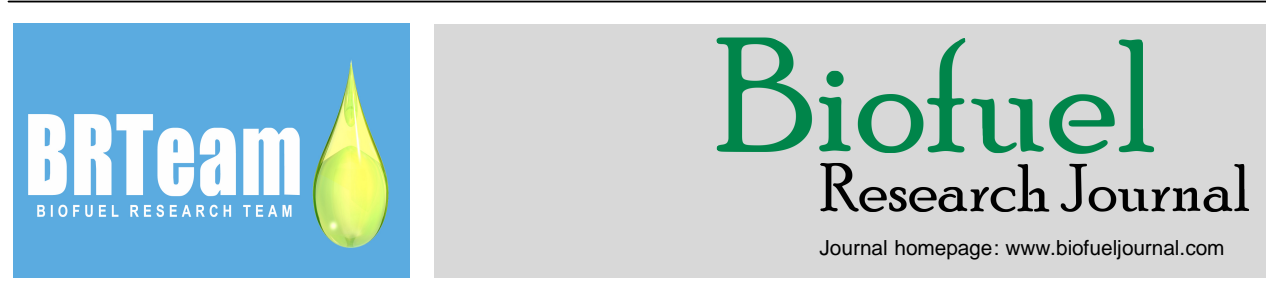

Journal homepage: www.biofueljournal.com

Review Paper

\title{
Second-generation bioethanol from industrial wood waste of South American species
}

\author{
María E. Vallejos, Julia Kruyeniski, María Cristina Area*
}

Programa de Celulosa y Papel - Instituto de Materiales de Misiones (CONICET-UNaM), Facultad de Ciencias Exactas Químicas y Naturales, Félix de Azara

1552 (3300), Misiones, Argentina.

\section{HIGHLIGHTS}

Second generation bioethanol is a viable option to valorize the residues of the South America forest industry.

$>$ Eucalyptus and pines are the most important woody raw materials in the region.

$>$ Autohydrolysis and alkaline treatments are effective options to pretreat Eucalyptus.

$>$ Novel and complex treatments or treatment

combinations are recommended for pine-based ethanol production.

$>$ Raw material price plays a key role in the cost distribution of cellulosic bioethanol.

\section{GRAPHICAL ABSTRACT}

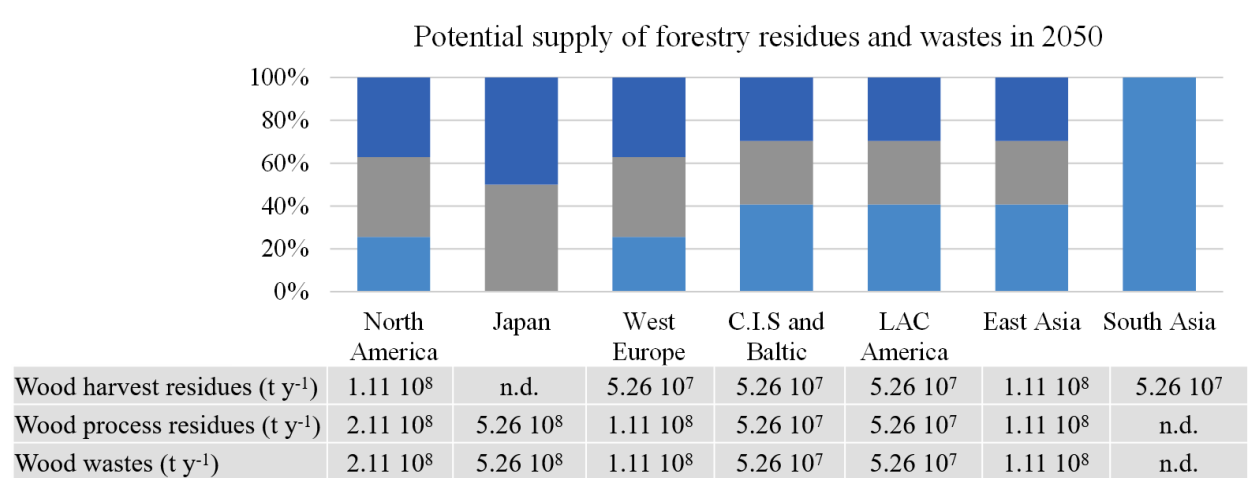

\section{ARTICLE INFO}

\section{Article history:}

Received 2 April 2017

Received in revised form 2 August 2017

Accepted 13 August 2017

Available online 1 September 2017

\section{Keywords:}

Second-generation ethanol

South America

Wood waste

Pinus

Eucalyptus

Biorefinery

\begin{abstract}
There is a global interest in replacing fossil fuels with renewable sources of energy. The present review evaluates the significance of South-American wood industrial wastes for bioethanol production. Four countries have been chosen for this review, i.e., Argentina, Brazil, Chile, and Uruguay, based on their current or potential forestry industry. It should be noted that although Brazil has a global bioethanol market share of $25 \%$, its production is mainly first-generation bioethanol from sugarcane. The situation in the other countries is even worse, in spite of the fact that they have regulatory frameworks in place already allowing the substitution of a percentage of gasoline by ethanol. Pines and eucalyptus are the usually forested plants in these countries, and their industrial wastes, as chips and sawdust, could serve as promising raw materials to produce second-generation bioethanol in the context of a forest biorefinery. The process to convert woody biomass involves three stages: pretreatment, enzymatic saccharification, and fermentation. The operational conditions of the pretreatment method used are generally defined according to the physical and chemical characteristics of the raw materials and subsequently determine the characteristics of the treated substrates. This article also reviews and discusses the available pretreatment technologies for eucalyptus and pines applicable to South-American industrial wood wastes, their enzymatic hydrolysis yields, and the feasibility of implementing such processes in the mentioned countries in the frame of a biorefinery.
\end{abstract}

* Corresponding author at: Tel.: +54-3764-422198

E-mail address: cristinaarea@gmail.com

Please cite this article as: Vallejos M.E., Kruyeniski J., Area M.C. Second-generation bioethanol from industrial wood waste of South American species.

Biofuel Research Journal 15 (2017) 654-667. DOI: 10.18331/BRJ2017.4.3.4 


\section{Contents}

1. Introduction

2. Forestry and wood waste in South America

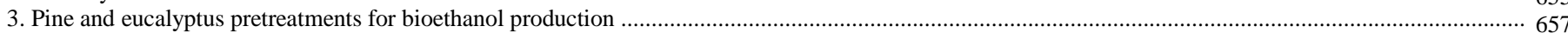

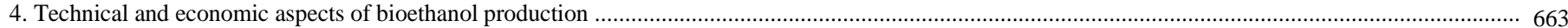

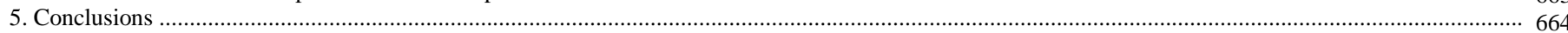

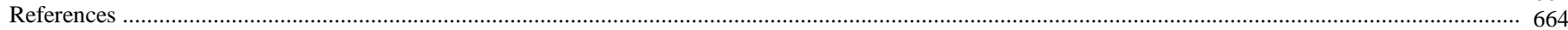

\section{Introduction}

The global use and production of biofuels have grown significantly in the last decade. The prominence of biofuels is evidenced by the increase of their production from 46 million $\mathrm{L}$ in 2006 to 118 million L in 2013 (Zaman et al., 2016). At commercial scale, ethanol is combined with gasoline, and biodiesel is blended with diesel. The main interest in biofuel production is attributed to the reductions achieved in the emission of greenhouse gasses (GHG) produced by fossil fuels. Nowadays, about $60 \%$ of the global bioethanol production is based on sugarcane while the rest is obtained mainly from corn and other crops. However, the use of edible crops for biofuels production has led to significant pressure on arable land originally used for the production of food crops and hence, investigation of other carbohydrate sources of no food/feed value is a necessity (Solomon and Bailis, 2014; Cremonez et al., 2015).

The development of bioethanol production responds more to social mandates rather than to economic issues. In fact, national and international policies including subsidies and tax exemptions, as well as biofuel blending mandate strongly encourage the production of biofuels (Laaksonen-Craig, 2008; Willem van Gelder et al., 2012; Cremonez et al., 2015). Without regulations, generally propped up by local producers or NGOs, bioethanol production would not have stood a chance to develop due to the fierce competition with the oil industry. For example, some of the recent regulations about biofuels in the European Union (i.e., Renewable Energy Directive 2009/28/EC, Fuel Quality Directive 2009/30/EC, and Directive to reduce indirect land use change for biofuels and bioliquids (EU)2015/1513), as well as in the United States (i.e., Energy Policy Act (EPAct) 2005 and 2013 Cellulosic Biofuel Standard, Final Rule, U.S. EPA, Vol. 79, No. 85, May 2, 2014) have targeted increased inclusion percentage of renewable fuels in gasoline with a focus on the use of cellulosic and lignocellulosic materials as raw materials (EBTP, 2009; Duffield et al., 2015). The United States has set forth plans to produce 60 billion L of second-generation biofuel, i.e., about $20 \%$ of its liquid transportation fuel, by the year 2022. These biofuel policies have driven the second-generation biofuel development (Eisentraut, 2010; Balan, 2014). North America, especially the United States, has been an outstanding leader in cellulosic ethanol production (Griffin et al., 2016). Extensive information about biofuels policies and regulations can be found in the literature (Solomon et al., 2007; Sorda et al., 2010; Solomon and Bailis, 2014).

In Brazil, Proalcool (National Ethanol Program) Decree n. 76.593, 1975, first mandated the addition of ethanol to gasoline for use in motor vehicles, initiating a great expansion of the bioethanol industry in the country. Later, Law 10.464 / 02, 2002, requested for a mandatory blend of between 20 and $25 \%$ (Cassuto and Gueiros, 2012). Pilot plants of second-generation bioethanol are already operating in Brazil but the financing needed for commercial plants of such is around of USD 125-250 million (Eisentraut, 2010). In Argentina, the Law 26.093, Regime of Regulation and Promotion for the Sustainable Production and Use of Biofuels, 2006, stipulated 5\% fuel bioethanol in the gasoline mix (Diputados, Senado y Cámara de Argentina, 2006). In line with that, Argentina produced around $350,000 \mathrm{~m}^{3}$ of first-generation bioethanol from sugarcane and corn in the year 2010 (García et al., 2011) but the mandate was never fulfilled (Biofuels-Digest, 2016). Nevertheless, recent regulations have raised the proportion of bioethanol in gasoline to $10 \%$ (Lemos and Mesquita, 2016). Chile has also announced the intention of developing secondgeneration biofuels but it lacks available biomass resources (Eisentraut, 2010).

The global production of bioethanol in the year 2015 was 90 billion L (Araújo, 2016) out of which the United States and Brazil accounted for more than 70\% (Achinas and Euverink, 2016). The liquid biofuels production also resulted for about 1.8 million jobs created worldwide in the year 2014, $47 \%$ of which took place in Brazil (Araújo, 2016). Latin America and the Caribbean reached a $27 \%$ of the worldwide biofuel production in the year 2012, mostly in the form of bioethanol and biodiesel (Solomon and Bailis, 2014). Brazil is the largest producer of ethanol in this region since the year 1960 and one of the main producers on a global scale. The market for first-generation ethanol is already established in Brazil, Colombia, and Argentina whilst it is in its developing stages in Paraguay and Bolivia as well (Janssen and Rutz, 2011).

The high volumes of wood industrialized in South American countries coupled with their intention to turn to renewable energies, make the secondgeneration bioethanol production a viable option to valorize the residues of the forest industry. It should be noted that the forest industry is in general relying increasingly on forests located in South America, Africa, and Asia (Toppinen et al., 2010). For example, pulp trade increased by 3\% in 2015 due to the startup of new pulp mills in Brazil and Uruguay (FAO, 2015). Uruguay has encouraged forestry in the last decades, and consequently, the new forest sector has grown rapidly, attracting foreign investments due to the attractive cost-benefit ratios (Olmos and Siry, 2009). The main forest cultures in South America are pines and eucalyptus. These species are globally considered as good raw materials for papermaking and wood products and are mainly industrialized in Brazil, Chile, Uruguay, and Argentina (FAO, 2006).

The use of the lignocellulosic biomass is considered as a sustainable pathway for biofuels production as substitution for fossil fuels. Life cycle assessment studies evaluating the environmental implications of the production of ethanol from fast-growing wood crops in comparison with conventional gasoline have shown reductions in almost all impact categories under assessment when shifting to ethanol-based fuels (González and García, 2015). Another advantage of or second-generation ethanol (cellulosic bioethanol) over the technologically mature firstgeneration ethanol is the ability to use different types of lignocellulosic materials as a source of glucose. In this context, lignocellulosic materials are being intensely studied as feedstocks for bioethanol production, while focusing on improving the technological processes involved in order to reduce the production cost of fermentable sugars and their fermentation to ethanol (Alvira et al., 2010; Zhu et al., 2010; Zhu and Pan, 2010; Solomon and Bailis, 2014; Achinas and Euverink, 2016; Araújo, 2016; Zabed et al., 2017). However, among sixteen commercial-scale cellulosic ethanol projects using sugar platform in the world in the year 2012, only one has been based on wood as raw material (Araújo, 2016).

The present manuscript briefly reviews forestry and wood industry in South America and the potentials for biofuels and particularly bioethano production. It also presents a short description of the main regional forest resources and their characteristics, including the availability of wood residues that could be potential sources for bioethanol production. Subsequently, available pretreatment technologies and their enzymatic hydrolysis (EH) yield for the main feedstocks of the South-American wood industry, i.e., eucalyptus and pines wood wastes were discussed. Finally, the feasibility of implementing relevant processes in the frame of a biorefinery for Argentina, Brazil, Chile, and Uruguay was presented.

\section{Forestry and wood wastes in South America}

Forest plantations in South America consist almost exclusively of fastgrowing exotic species. For example, Eucalyptus and Pinus in Brazil have rotation lengths of 8-10 and 16-25 years and mean annual increments of 1820 and $15-25 \mathrm{~m}^{3} \mathrm{ha}^{-1} \mathrm{yr}^{-1}$, respectively (FAO, 2001). Much progress has been made in the improvement of the yield and in the silviculture of fastgrowing species, since in Argentina, for example, the growth is almost two folds that of two decades ago. In addition to the geographical advantages, this is due to the permanent development of silvicultural techniques oriented to improve the productivity and sustainability of the plantations. 
Plantations have been observed in recent times due to their alleged negative effects on water resources, soil, and biodiversity. Hence, efforts have been intensified to design plantations adapted to specific conditions of each region, and site, with the purpose of minimizing or totally avoiding such effects, and on the contrary to increase the production of environmental services such as watershed regulation, carbon capture, and soil stabilization (Idígoras, 2016).

The most relevant species and the most suitable lignocellulosic wastes potentially available as feedstock for the production of ethanol in South America are shown in Table 1. The advantages of wood wastes compared with agro-industrial wastes are related to the harvesting, storage, and transportation. Wood wastes are in general unexploited resources with great potential for ethanol production (220-285 L/ton of wood). They have low ash content and their transport cost is low because of their high density, as compared with agro-industrial wastes (Zabed et al., 2017).

Most wastes from sawmills in Argentina and Brazil are scarcely utilized and are usually burned for energy production. In Brazil and based on the data recorded in the year 2007, about $30 \%$ of the forestry processing residues $(5,500,000$ tons of dry matter per year) were unused (Kline et al. 2008). The projections of the wastes and biomass associated with current

Table 1.

Forest resources and lignocellulosic wastes available as feedstock for the production of $2^{\text {nd }}$ generation bioethanol in South America.

\begin{tabular}{|c|c|c|c|c|c|c|c|}
\hline Country & Region & $\begin{array}{l}\text { Harvesting } \\
\text { area (ha) }\end{array}$ & Plant type or waste & $\begin{array}{l}\text { Area } \\
(\%)\end{array}$ & $\begin{array}{l}\text { Amount of } \\
\text { waste (ton/y) }\end{array}$ & $\begin{array}{l}\text { Ethanol } \\
\text { production } \\
\text { potential }\end{array}$ & Refference \\
\hline Argentina & Total country & $\begin{array}{l}648,000 \\
384,000 \\
108,000 \\
60,000\end{array}$ & $\begin{array}{l}\text { Pinus elliottii and Pinus taeda } \\
\text { Eucalyptos } \\
\text { Salicaceae }(\%) \\
\text { Others }\end{array}$ & $\begin{array}{l}54 \\
32 \\
9 \\
5\end{array}$ & $\begin{array}{l}- \\
- \\
- \\
-\end{array}$ & $\begin{array}{l}- \\
- \\
-\end{array}$ & Senasa (2014) \\
\hline Argentina & Misiones & 200,000 & $\begin{array}{l}\text { Pinus elliottii and Pinus taeda } \\
\text { Total wood waste } \\
\text { Wood waste available }\end{array}$ & $\begin{array}{l}- \\
- \\
-\end{array}$ & $\begin{array}{l}- \\
2,101,494 \\
416,096 \\
\end{array}$ & $\begin{array}{l}- \\
- \\
-\end{array}$ & $\begin{array}{l}\text { Area and Vallejos (2012) } \\
\text { PROBIOMASA (2012) } \\
\text { Stoffel (2016) }\end{array}$ \\
\hline Argentina & Mesopotamian region & 200,000 & $\begin{array}{l}\text { E. grandis, E. saligna, and E. dunni } \\
\text { Eucalyptus wastes }\end{array}$ & $\begin{array}{l}52 \% \\
\text { with } \\
\text { respect } \\
\text { to total }\end{array}$ & - & 400,000 & $\begin{array}{l}\text { Carpineti (1995) } \\
\text { Ruz et al. (2014) }\end{array}$ \\
\hline Argentina & $\begin{array}{l}\text { Delta region and south of } \\
\text { Argentina }\end{array}$ & - & Salicaceae & 9 & - & - & Senasa (2014) \\
\hline Argentina & Córdoba & - & Corncobs & - & 100,000 & - & Ruz et al. (2014) \\
\hline Argentina & San Juan and Mendoza & - & Vineyard pruning & - & 235,000 & - & Ruz et al. (2014) \\
\hline Argentina & Tucumán & - & $\begin{array}{l}\text { Sugarcane straw } \\
\text { Sugarcane bagasse }\end{array}$ & $\begin{array}{l}- \\
-\end{array}$ & $\begin{array}{l}260,000 \\
200,000 \\
\end{array}$ & $\begin{array}{l}- \\
-\end{array}$ & Ruz et al. (2014) \\
\hline Brazil & - & - & E. grandis and E. urophylla & - & - & - & Castro et al. (2016) \\
\hline Brazil & $\begin{array}{l}\text { North, south east, and south } \\
\text { of Brazil } \\
\text { South east and south of } \\
\text { Brazil }\end{array}$ & - & $\begin{array}{l}\text { Forestry waste } \\
\text { Sawdust }\end{array}$ & - & $\begin{array}{l}4,300,000 \\
1,185,000\end{array}$ & - & Kline et al. (2008) \\
\hline Brazil & $\begin{array}{l}\text { Alagoas and Pernambuco, } \\
\text { Goiás, Mato Grosso do Sul, } \\
\text { Sao Paulo, Minas Gerais, } \\
\text { Paraná }\end{array}$ & - & Sugarcane straw and bagasse & - & $\begin{array}{l}500,000 \text { to } \\
2,000,000 \text { per } \\
\text { season }\end{array}$ & - & Ruz et al. (2014) \\
\hline Chile & $\begin{array}{l}\text { O'Higgins and Los Lagos } \\
\text { regions } \\
\text { The whole country }\end{array}$ & 2.872 million & $\begin{array}{l}\text { Pinus radiata } \\
\text { Eucalyptus } \\
\text { Pinus radiata } \text { waste (cellulosic } \\
\text { industry) } \\
\text { Eucalyptus waste (cellulosic industry) }\end{array}$ & $\begin{array}{l}68 \\
23 \\
- \\
-\end{array}$ & $\begin{array}{l}- \\
- \\
2,234,000 \\
-\end{array}$ & $\begin{array}{l}- \\
- \\
- \\
-\end{array}$ & $\begin{array}{l}\text { CONAF (2011) } \\
- \\
\text { CNE/GTZ (2008) } \\
-\end{array}$ \\
\hline & The whole country & & - & - & 536,000 & - & CNE/GTZ (2008) \\
\hline Chile & Araucania region & - & Wheat straw & - & 500,000 & - & Ruz et al. (2014) \\
\hline Chile & O’Higgins region & - & Corncobs & - & 500,000 & - & Ruz et al. (2014) \\
\hline Chile & $\begin{array}{l}\text { Coquimbo, Valparaíso, } \\
\text { Metropolitana, O’Higgins, } \\
\text { and Maule } \\
\end{array}$ & - & Apple and vineyard pruning & - & $\begin{array}{l}150,000 \text { to } \\
280,000\end{array}$ & - & Ruz et al. (2014) \\
\hline \multirow{3}{*}{ Uruguay } & $\begin{array}{l}\text { Total } \\
\text { Departments of Paysandú } \\
\text { and Rio Negro } \\
\text { Departments Paysandú and }\end{array}$ & - & $\begin{array}{l}\text { Eucalyptus } \\
\text { E. dunnii, }\end{array}$ & $\begin{array}{l}99 \% \\
58 \% \text { of } \\
\text { the total }\end{array}$ & $\begin{array}{l}- \\
-\end{array}$ & $\begin{array}{l}- \\
-\end{array}$ & $\begin{array}{l}\text { Boscana and Boragno (2016) } \\
\text { Boscana and Boragno (2016) }\end{array}$ \\
\hline & Rivera & & E. grandis, & $\begin{array}{l}29 \% \text { of } \\
\text { the total }\end{array}$ & - & - & Boscana and Boragno (2016) \\
\hline & & & Total Eucalyptus forestry residues & - & $\begin{array}{l}90,000 \text { to } \\
140,000\end{array}$ & - & Ruz et al. (2014) \\
\hline Uruguay & $\begin{array}{l}\text { Departments of Tacuarembó } \\
\text { and Rivera }\end{array}$ & - & Pinus (P. taeda), & - & - & - & Boscana and Boragno (2016) \\
\hline Paraguay & Guaira & - & Sugarcane bagasse & - & 54,000 & - & Ruz et al. (2014) \\
\hline
\end{tabular}


forestry activities which are potentially available for bioethanol production between the years 2017 and 2027 in Brazil and Argentina could stand at $7,800,000$ and 500,000 of metric tons, respectively.

Biomass wastes derived from the lumber industry (sawdust, bark, and harvesting residues) can reach 1.8 million of $\mathrm{m}^{3}$ in Chile between 2019 and 2021. These wastes are used as industrial fuel to generate heat and electricity (Berg and Segura, 2016). A current ongoing initiative is the consortium BIOENERCEL S.A., which was created to develop technologies and human resources for the conversion of lignocellulosic biomass to ethanol and biodiesel (García et al., 2011).

The estimation of the available volumes of current and potential lignocellulosic materials from wood wastes is tough to quantify due to the social and environmental complexity of the scenarios. However, the potential growth of the forest surplus in the year 2050, in a scenario of average plantations and demands, is estimated at $6.4 \mathrm{Gm}^{3}\left(74 \mathrm{EJ} \mathrm{yr}^{-1}\right)$ where $40 \%$ is expected to end up as wastes. Figure 1 shows the proportion of forest residues and wastes potentially available, estimated from a study on the global bioenergy potentials towards 2050 .
Cellulose, hemicelluloses, and lignin are the main components of wood in all trees. Lignin is formed by random copolymers deriving from unsaturated alcohol derivatives of phenyl-propane, having several functional groups as methoxyl, phenyl hydroxyl, benzyl alcohol, and carbonyl groups. Hemicelluloses are composed mostly of glucuronoxylan, glucomannan, galactoglucomannans, arabinoxylans, and glucuronoarabinoxylans in hardwoods and gramineous plants, whereas they are formed mainly of galactoglucomannans, arabinoglucuronoxylan, and arabinogalactan in softwoods. Cellulose is formed by linear polymers of $\beta$ (1-4) D-glucopyranosyl units, mostly aggregate in crystalline, highly ordered structural entities. Hardwoods and softwoods also have minor but varying amounts of extractives as fats, waxes, alkaloids, proteins, gums, resins, starches, and ash (Vallejos et al., 2017). Lignin is not bound directly to cellulose, but it is covalently bound to hemicelluloses, which is in direct relation with the swelling capacity of wood (Salmén and Burgert, 2009).

A comparison of the chemical composition of regional (South American) woods is shown in Table 2.

The data presented in the table reveal the great variations in chemical

\section{Potential supply of forestry residues and wastes in 2050}

\begin{tabular}{|r|c|c|c|c|c|c|c|}
\hline $100 \%$ & & & & & & \\
\\
$80 \%$
\end{tabular}

Fig.1. Proportion of forest residues and wastes potentially available, estimated from a study of the global bio-energy potentials to 2050 (adapted from Smeets et al., 2007). * n.d.: not defined.

Wood harvest residues are twigs, branches, and stumps. Industrial process residues are residues generated during the processing of wood into final products. Most wood processing residues are sawdust and wood chips. Wood waste is discarded wood products, such as waste paper and demolition wood. The estimated bioenergy potential of wood wastes based on their energy content on dry basis ranges from 17 to $21 \mathrm{MJ} / \mathrm{kg}$ are (average $19 \mathrm{MJ} / \mathrm{kg}$ ) and accordingly, bioenergy production potentials at global scale will be: wood harvest residues $8 \mathrm{EJ} \mathrm{yr}^{-1}$, wood process residues $11 \mathrm{EJ} \mathrm{yr}^{-1}$, and wood waste $11 \mathrm{EJ} \mathrm{yr}^{-1}, 1 \mathrm{EJ}=10^{18} \mathrm{~J}$ (Smeets et al., 2007; González and González, 2015).

The wood of the genus Eucalyptus has a similar structure, indistinctly of the species. They have libriform fibers for mechanical support (between 40 and $80 \%$ of the tissue), fiber-tracheids, and vasicentric tracheids for both transport and support, and vessel cells with tubular form elements that are interconnected to form long vessels for liquids transport. Despite this, there is a great variation in density and durability among species. For example, the specific gravity of $E$. grandis varies between 0.48 and 0.64 , whereas that of E. globulus is 0.68-0.82 and for E. camaldulensis (industrialized wood) is 0.67-0.87 (Meier, 2015).

On the contrary, ninety percent of the wood structure of conifers is formed by a single kind of longitudinal cells (tracheids) which perform both liquid transport and support (Area and Popa, 2014). Loblolly pine has greater growth rates and is more suitable for the pulp industry and some uses of wood whereas slash pine is a rustic species which produces resin, sometimes commercialized as a by-product. Both loblolly and slash pines are harder, denser (specific gravities: 0.41-0.51 P. radiata; 0.47-0.57 P. taeda; 0.54-0.66 P. elliotti), and possess better strength-to-weight ratio than radiata pine (Meier, 2015). composition due to the different species and ages of the trees. For example, old trees of E. camaldulensis (red eucalyptus), widely used in sawmills, show a composition totally different from E. grandis used for pulp manufacture, proving that the processes of conversion of raw materials into sugars for bioethanol production must be optimized in each case.

\section{Pine and eucalyptus pretreatments for bioethanol production}

A pretreatment is essential to make cellulose more accessible to the enzymatic attack for the production of second generation bioethanol. The requirements that an effective pretreatment should meet are (Bengoechea et al., 2012):

- Reduction of the crystallinity of cellulose.

- Elimination of acetyl groups from hemicelluloses.

- Elimination of the bonds between hemicelluloses and lignin, with the consequent separation of lignin.

- Increase in the surface area of the material.

- Obtaining high yield of sugars (hexoses and pentoses).

- Minimal formation of toxic degradation products to avoid or simplify the detoxification stage.

- Low energy consumption and investment cost.

- Use of cheap and easily recoverable reagents.

- Minimal degradation of hemicellulosic sugars.

The most promising strategy is to integrate ethanol production within a biorefinery scheme in which lignin, hemicelluloses, and extractives from the lignocellulosic biomass would be converted into high-value coproducts. 
Table 2.

Comparative chemical composition of regional Pinus and Eucalyptus.

\begin{tabular}{|c|c|c|c|c|c|c|c|}
\hline Component (\%) & P. elliotti* (1) & P. radiata** (2) & P. taeda* (3) & E. camaldulensis* (4) & E. grandis** (5) & E. viminalys $* *(6)$ & E. globulus *(7) \\
\hline Cellulose & 46.6 & 41.2 & 41.0 & 41.8 & 51.1 & 47.71 & 43.8 \\
\hline Hemicelluloses & 22.0 & 26.0 & 10.5 & 12.11 & 19.2 & 23.08 & 20.7 \\
\hline Lignin & 27.2 & 27.8 & 31.5 & 31.3 & 26.2 & 25.00 & 27.1 \\
\hline $\begin{array}{l}\text { Extractives } \\
\text { (organic solvent) }\end{array}$ & 4.60 & 1.90 & 6.00 & 6.59 & 1.20 & 3.72 & 1.80 \\
\hline Ashes & - & - & 0.40 & 0.59 & 0.20 & 0.49 & - \\
\hline
\end{tabular}

* Old trees; ** 8-9 years-old trees; (1) Stoffel et al. (2014); (2) Estimated from Reyes et al. (2013); (3) Mattos et al. (2016); (4) Rangel et al. (2016); (5) Estimated from Fardim and Durán

(2004); (6) Estimated from Ramos et al. (2000); (7) Estimated from Reina and Resquin (2011).

This would assist with compensating for the costs associated with pretreatment and enzymes used for the hydrolysis of cellulose. The biorefinery thereby extends the concept of pretreatment to a fractionation of the material, obtaining fractions as pure as possible for their use and transformation into high-value products.

The most studied pretreatments and their effects are:

- Mechanical treatments (milling, extrusion, thermomechanical, refining): decrease the size of the particles to increase the surface area making them more accessible to enzymes.

- Hot water (auto-hydrolysis): liquid hot water treatment leads to deacetylation of xylans, acidifying the solution with acetic acid which catalyzes the hydrolysis of hemicelluloses, mostly in case of hardwood and grasses.

- Dilute acid: hydrolyzes hemicelluloses and the less crystalline cellulose into sugars, generating also degradation products.

- Steam explosion: the injection of high-pressure saturated steam followed by a sudden decompression to atmospheric pressure produces the separation of fibers and the depolymerisation and breaking of lignincarbohydrates bonds, promoting the extraction o hemicelluloses.

- Supercritical $\mathrm{CO}_{2}$ : leads to impregnation and is effective to extract substances of low polarity. It also acts as a mildly acidic extraction and saccharification system for hemicelluloses.

- Organosolv delignification (catalyzed with acids or alkalis): catalysts break the internal bonds between lignin and hemicelluloses and the solvent promotes the extraction of lignin.

- Sulfite delignification in acid media: extracts lignin from wood in the form of lignosulfonates and also hemicelluloses, depending on the strength of the liquor and the severity of the conditions used.

- $\quad$ Alkaline delignification (kraft process, oxygen delignification): leads to the swelling of the fibers and extracts mostly lignin by splitting of lignincarbohydrates bonds and lignin hydrolysis.

- Ultrasonic irradiation: enhances chemical treatments.

- Biological treatment by microorganisms or enzymes: produce wood degradation components, increasing porosity.

- Ionic liquids: result in biomass dissolution and promote structural changes in the regenerated biomass by reduction of cellulose crystallinity and lignin content.

A detailed description of all these processes, including their mechanisms, characteristics, advantages, and disadvantages, can be found in Brodin et al. (2017). Since the different lignocellulosic materials have different physicochemical characteristics, it is necessary to adopt appropriate pretreatment/s for each one.

Softwoods have been recognized as a highly recalcitrant raw material to $\mathrm{EH}$ (Morales et al., 2017). Several studies and reviews in the last years include generically softwoods, mixed softwoods or refer mostly to spruce and fir as a source for bioethanol production (Pan et al., 2005; Wingren et al., 2008; Inoue et al., 2016; Alvarez-Vasco and Zhang, 2017). Literature about bioethanol production from pines is limited, and specifically about South-American pines is non-existent. A summary of pretreatments atempted in the last years to increase enzymatic digestibility of pine substrates is shown in Table 3 .

Most relevant pretreatments studied to increase enzymatic digestibility of eucalyptus substrates are shown in Table 4.
For a better visualization of the relationship between processes and $\mathrm{EH}$ the pretreatments referenced in Table 3 and 4 were grouped in order of $\mathrm{EH}$ as low, medium, and high, and were schematized as shown in Figures 2,3, and 4 (pine) and Figures 5, 6, and 7 (eucalyptus). Since references were heterogeneous in the form to express $\mathrm{EH}$ yields, the non-comparable schemes were excluded.

General studies have stated that dilute acid hydrolysis followed by EH is a promising technology for all raw materials, including pines (Galbe and Zacchi, 2002; Chandel et al., 2007). Nevertheless, the achieved digestibility is rather low in spite of the increasingly complex quantity and the variety of pre-treatments tested for pine in the last two years (Tian et al., 2016; Rajagopalan et al., 2017; and others listed down in Table 3).

Most studied processes for pines include mechanical and acid pretreatments followed by alkaline or organosolv delignification. Results of EH are generally poor, with few cases above $90 \%$. Best digestibilities (EH > 90\%) were obtained on sawdust, using alkaline treatments without a previous additional stage. The only exception was a case of radiata pine bu it may be ascribed to its comparatively low density, as mentioned in Section 2. The operational conditions of the pretreatment methods are defined according to the physical and chemical characteristics of the raw material and determine the characteristics of the treated substrate. The digestibility of pine with high lignin content is low, so some lignin must be extracted (Meier, 2015; Kruyeniski et al., 2016a). The intention of acid pretreatments is to extract hemicelluloses to increase porosity, but it does not result in an improvement in the $\mathrm{EH}$ of pines because of lignin condensation, being harmful to its final form and use (Sannigrahi et al., 2008; Stoffel et al., 2014). In conclusion, new processes must be developed and optimized to improve the digestibility of resinous pines.

Like for pines, the best results for eucalyptus EH (between $90 \%$ and $100 \%$ ) could be obtained by delignification treatments. Nevertheless, in this case, the inclusion of a previous additional stage involving hot water with or without acid (acid hydrolysis or autohydrolysis generated by the deacetylation of xylans) could lead to enhanced EH. Unlike pines, it is possible to apply a combination of acids, alkalis, and solvents when handling eucalyptus without producing a significant condensation of lignin, to obtain high EH yields and byproducts (Figures 3, 4,6 and 7). This allows the extraction and exploitation of hemicelluloses and lignin in the biorefinery context. However, the recovery of chemicals and the scale of production should also be taken into account when delignifying processes such as kraft or sulfite are included. On the contrary, the application of treatments such as ionic liquids or complex solvents seems not to be so effective in enhancing the $\mathrm{EH}$ of these hardwoods. It is also clear that high enzyme charges would not be needed to increase digestibility if the correct pretreatment would be applied.

Comparing the EH data in the different schemes, it is evident that eucalyptus wood is less recalcitrant to EH than pine wood, and that there is already a sufficient study background to define applicable pretreatment technologies with smaller adjustments.

Almost all reports on pines and eucalyptus indicate that pretreatments should involve mechanical treatment for size reduction of the raw material as well. This is unnecessary when using wood wastes like sawdust, which is a basic advantage reducing costs and technological complexity. However, studies on pretreatments for bioethanol production from both 
Table 3.

Summary of pretreatments methods used for pine and their corresponding enzymatic digestibility

\begin{tabular}{|c|c|c|c|c|}
\hline Raw material* & Origin & Pretreatments and conditions & $\begin{array}{l}\text { Maximum enzymatic } \\
\text { digestibility }\end{array}$ & Reference \\
\hline $\begin{array}{l}\text { Southern yellow pine } \\
\text { sawdust }\end{array}$ & USA & $\begin{array}{l}\text { Supercritical } \mathrm{CO}_{2} \text { treatment: } 3100 \mathrm{psi}, 165^{\circ} \mathrm{C}, 30 \mathrm{~min} \\
\text { EH: Cellulase enzyme complex }(200 \mathrm{mg} / \mathrm{g} \text { substrate }), 50^{\circ} \mathrm{C}, 72 \mathrm{~h}\end{array}$ & $\begin{array}{l}\text { Untreated: } 12.8 \% \\
\text { Treated: } \approx 17.6 \%(\mathrm{w} / \mathrm{w})\end{array}$ & Kim and Hon (2001) \\
\hline Pinus contorta & Canada & $\begin{array}{l}\text { 1. Steam explosion treatment: } 200^{\circ} \mathrm{C}, 4.0 \% \mathrm{SO}_{2}(\mathrm{w} / \mathrm{w}), 5 \mathrm{~min} \\
\text { 2. Organosolv delignification: ethanol:water } 65: 35 \%(\mathrm{v} / \mathrm{v})+1.1 \% \mathrm{SO}_{4} \mathrm{H}_{2} \text {, } \\
170^{\circ} \mathrm{C}, 60 \mathrm{~min} \\
\text { EH: cellulase }(20 \mathrm{FPU}) \text { and } \beta \text {-glucosidase }(40 \mathrm{IU}), 45^{\circ} \mathrm{C}, 48 \mathrm{~h}+\text { addition of } \\
\text { Surfactants }\end{array}$ & $\begin{array}{l}1+2 \\
\text { Without surfactant with } \mathrm{EH} \approx 60 \% \\
\text { With surfactant with } \mathrm{EH}: \approx 90 \%\end{array}$ & Tu et al. (2007) \\
\hline Pinus contorta & Canada & $\begin{array}{l}\text { Organosolv delignification: ethanol:water } 65: 35 \%(\mathrm{v} / \mathrm{v})+1.1 \% \mathrm{SO}_{4} \mathrm{H}_{2} \text {, } \\
187^{\circ} \mathrm{C}, 60 \mathrm{~min} \\
\text { EH: cellulase }(20 \mathrm{FPU}) \text { and } \beta \text {-glucosidase }(40 \mathrm{IU}), 50^{\circ} \mathrm{C}, 48 \mathrm{~h}\end{array}$ & $100 \%$ cellulose to glucose yield & Pan et al. (2008) \\
\hline Red pine & USA & $\begin{array}{l}\text { Sulfite treatment to overcome recalcitrance of lignocellulose (SPORL): } \\
\text { 1. Magnesium bisulfite } 8 \% \text { odw }(\mathrm{w} / \mathrm{w}), 3.68 \% \text { odw sulfuric acid, } 30 \mathrm{~min} \text { at } \\
\text { Tmax }\left(180^{\circ} \mathrm{C}\right) \\
\text { 2. Atmospheric disk milling (disk gap } 0.25 \mathrm{~mm}) \text {. } \\
\text { EH: Cellulase ( } 20 \mathrm{FPU} / \mathrm{g} \text { cellulose) and } \beta \text {-glucosidase ( } 30 \mathrm{CBU} / \mathrm{g} \text { cellulose), } \\
50^{\circ} \mathrm{C}, 72 \mathrm{~h}\end{array}$ & $1+2100 \%$ cellulose conversion & Zhu et al. (2009) \\
\hline Pinus rigida & South Korea & $\begin{array}{l}\text { Organosolv delignification: } 50: 50 \%(\mathrm{v} / \mathrm{v}) \text { ethanol:water+ } \\
\text { a. } 1 \% \mathrm{SO}_{4} \mathrm{H}_{2} \\
\text { b. } \quad 1 \% \mathrm{MgCl}_{2} \\
\text { c. } \quad 2 \% \mathrm{NaOH} \\
170-210^{\circ} \mathrm{C}, 20 \text { min } \\
\text { EH: Cellulase enzyme complex } 50^{\circ} \mathrm{C}, 72 \mathrm{~h}\end{array}$ & $\begin{array}{ll}\text { a. } & 55-60 \% \\
\text { b. } & 60 \% \\
\text { c. } & 80 \%\end{array}$ & Park et al. (2010) \\
\hline Pinus taeda & USA & $\begin{array}{l}\text { 1. Mechanical treatment (milling): pass a } 5 \mathrm{~mm} \text { screen } \\
\text { 2. Organosolv delignification: } 65 \% \text { ethanol/water solution, } 1.1 \% \mathrm{SO}_{4} \mathrm{H}_{2} \text {, } \\
170^{\circ} \mathrm{C}, 1 \mathrm{~h} \\
\mathrm{EH}: \text { cellulose ( } 8 \mathrm{FPU} / \mathrm{g} \text { cellulose) and } \beta \text {-glucosidase ( } 16 \mathrm{IU} / \mathrm{g} \text { cellulose), } \\
50^{\circ} \mathrm{C}, 80 \mathrm{~h}\end{array}$ & $\begin{array}{l}1+2 \\
70 \%\end{array}$ & Sannigrahiet et al. (2010) \\
\hline Pine wood chips & USA & $\begin{array}{l}\text { Mechanical treatment: Extrusion (single screw extruder), } \\
3: 1 \text { compression ratio, } 150 \mathrm{rpm} \text { screw speed, } 1800^{\circ} \mathrm{C} \text { barrel temperature } \\
\text { EH: cellulase }(15 \mathrm{FPU} / \mathrm{g}) \text { and } \beta \text {-glucosidasein a } 1: 4 \text { ratio }, 50^{\circ} \mathrm{C}, 48 \mathrm{~h}\end{array}$ & $65.8 \%$ of cellulose recovery & Karunanithy et al. (2012) \\
\hline $\begin{array}{l}\text { Pinus taeda chips } \\
(1.0 \times 2.0 \times 0.3 \mathrm{~cm})\end{array}$ & USA & $\begin{array}{l}\text { Organosolv delignification: } 65 \% \text { ethanol, } 1.1 \%(\mathrm{w} / \mathrm{w}) \mathrm{SO}_{4} \mathrm{H}_{2}, 170^{\circ} \mathrm{C}, 60 \mathrm{~min} \\
\mathrm{EH} \text { : cellulase }(20 \mathrm{FPU} / \mathrm{g}) \text { and } \beta \text {-glucosidase, } 2 \% \text { consistency (w/w glucan), } \\
48^{\circ} \mathrm{C}, 72 \mathrm{~h}\end{array}$ & $70 \%$ & Li et al. (2013) \\
\hline Loblolly pine & USA & $\begin{array}{l}\text { Alkaline delignification: } \\
\text { 1. Kraft process: } \mathrm{H} \text { factor } 1500,18 \% \text { active alkali, } 25 \% \text { sulfidity } \\
\text { 2. Oxygen delignification: } 0.7 \mathrm{MPa}, 6 \% \mathrm{NaOH}, 110^{\circ} \mathrm{C}, 60 \mathrm{~min} \\
\text { 3. Refining: PFI mill, } 9000 \mathrm{rev} \\
\text { EH: Cellulase enzyme complex ( } 10 \mathrm{FPU} / \mathrm{g} \text { substrate), } 50^{\circ} \mathrm{C}, 96 \mathrm{~h}\end{array}$ & $\begin{array}{l}1+2+3 \\
\text { Sugar yield: } 87.6 \%\end{array}$ & Wu et al. (2014) \\
\hline Pine & Iran & $\begin{array}{l}\text { Mechanical treatment (milling): } 20-80 \text { mesh } \\
\text { 1. Hot water treatment: } 180^{\circ} \mathrm{C} ; 60 \mathrm{~min} \\
\text { 2. Organosolv delignification: } 75 \%(\mathrm{v} / \mathrm{v}) \text { ethanol }+1 \% \mathrm{w} / \mathrm{w} \mathrm{SO}_{4} \mathrm{H}_{2} ; 180^{\circ} \mathrm{C} \text {, } \\
15 \mathrm{~min}+60 \mathrm{~min} \\
\mathrm{EH}: \text { Cellulase enzyme complex, }(25 \mathrm{FPU} / \mathrm{g} \text { oven dry weight biomass), } \\
45^{\circ} \mathrm{C}, 72 \mathrm{~h}\end{array}$ & $\begin{array}{l}1 .+2 \text {. } \\
\approx 25 \%\end{array}$ & Amiri and Karimi (2016) \\
\hline
\end{tabular}

Mechanical treatment: Milling, particles less $1 \mathrm{~mm}$

\begin{tabular}{|c|c|c|c|c|}
\hline Pine & Iran & $\begin{array}{l}\text { 1. Ultrasonic irradiation: input power } 355 \mathrm{~W} \text {, frequency: } 45 \mathrm{kH}, 60^{\circ} \mathrm{C} ; 60 \mathrm{~min} \\
\text { 2. Anaerobic biological treatment: inoculum } 40 \mathrm{~mL} \text {, substrate } 0.5 \mathrm{~g} \text {, deionized } \\
\text { water } 10 \mathrm{~mL} ; 27 \text { days, } 37^{\circ} \mathrm{C} \\
\text { EH: cellulase }\left(30 \mathrm{FPU} / \mathrm{g} \text { ) and } \beta \text {-glucosidase }(50 \mathrm{IU} / \mathrm{g}), 45^{\circ} \mathrm{C}, 72 \mathrm{~h}\right.\end{array}$ & $\begin{array}{l}1+2=27.3 \% \\
2=17.5 \%\end{array}$ & Bahmani et al. (2016) \\
\hline Pinus taeda $\mathrm{L}$. & USA & $\begin{array}{l}\text { Organosolv delignification:55\% ethanol, } 1 \% \mathrm{SO}_{4} \mathrm{H}_{2}, 170^{\circ} \mathrm{C}, 60 \mathrm{~min} \\
\text { EH: Cellulase enzyme complex ( } 60 \mathrm{FPU} / \mathrm{g} \text { glucan }), 48 \mathrm{~h}, 55^{\circ} \mathrm{C}\end{array}$ & $\approx 75 \%$ yield & Heringer (2016) \\
\hline
\end{tabular}

Mechanical treatment (milling): 0.5-1.0 mm size particles.

1. Alkaline hydrogen peroxide (AHP): $50 \mathrm{~g} / \mathrm{L} \mathrm{KOH}^{2} 50 \mathrm{~g} / \mathrm{L} \mathrm{H}_{2} \mathrm{O}_{2} ; 78^{\circ} \mathrm{C} \cdot 24 \mathrm{~h}, 1$. AHP: $61.84 \pm 1.08 \%$

1. Alkaline hydrogen peroxide (AHP):

$50 \mathrm{~g} / \mathrm{L} \mathrm{H}_{2} \mathrm{O}_{2} ; 78^{\circ} \mathrm{C} ; 24 \mathrm{~h}$

2. EHOs: $75.18 \pm 0.85 \%$

Jain and Bridges (2016)

EH: Cellulase enzyme complex (80.2 FPU/g biomass), $50^{\circ} \mathrm{C}, 72 \mathrm{~h}$

\begin{tabular}{|c|c|c|c|c|}
\hline Pinus strobes L. & Canada & $\begin{array}{l}\text { Mechanical treatment (milling): pass } 80 \text {-mesh sieve. } \\
\text { Organic electrolyte solution (OES): room temperature ionic liquids (RTILs) + } \\
\text { polar organic solvent: DMSO }+0.1 \text { to } 0.9 \text { [AMIM]Cl } \\
\text { EH: Cellulase enzyme complex }\left(16.6 \mathrm{FPU} / \mathrm{g} \text { biomass), } 50^{\circ} \mathrm{C}, 120 \mathrm{~h}\right.\end{array}$ & $\begin{array}{l}\text { Without treatment: } \\
10.5 \pm 0.2 \% \\
63.0 \pm 2.3 \% \text { with } \chi_{[\text {AMIM }] \mathrm{Cl}}=0.8\end{array}$ & Tian et al. (2016) \\
\hline
\end{tabular}

Organosolv delignification: 50:50\% (v/v) ethanol:water, $1.1 \% \mathrm{w} / \mathrm{w}$

$\mathrm{H}_{2} \mathrm{SO}_{4}, 189^{\circ} \mathrm{C}, 8 \mathrm{~min}$
$\mathrm{EH}$ : Cellulase enzyme complex $(0.044 \mathrm{~g} / \mathrm{g}$ dry pretreated material $), 50^{\circ} \mathrm{C}, 72 \mathrm{~h}$

Hydrolysis yield: $82.94 \pm 1.34 \%$ 
Table 3.

(Continued).

\begin{tabular}{|c|c|c|c|c|}
\hline Raw material* & Origin & Pretreatments and conditions & $\begin{array}{l}\text { Maximum enzymatic } \\
\text { digestibility }\end{array}$ & Reference \\
\hline Pinus elliottii sawdust & Argentina & $\begin{array}{l}\text { Alkaline extraction }+ \text { diluted acidtretment: } \\
\begin{aligned} \text { a. } \quad \text { Acid hydrolysis } \\
\text { b. Steam explosion } \\
\text { c. } \quad \mathrm{a}+\mathrm{O}_{2}\end{aligned} \\
\mathrm{EH} \text { : Cellulase }(20 \mathrm{FPU} / \mathrm{g} \text { glucan }) \text { and } \beta \text {-glucosidase (40IU/g glucan), } \\
\mathrm{pH} 4.8,50^{\circ} \mathrm{C}, 72 \mathrm{~h}\end{array}$ & $\begin{array}{l}\text { a. } 7.5 \% \text { glucose } \\
\text { b. } 24 \% \\
\text { c. } 36 \%\end{array}$ & Stoffel (2016) \\
\hline $\begin{array}{l}\text { Pinus elliottii } \\
\text { sawdust }\end{array}$ & Argentina & $\begin{array}{l}\text { Alkaline and alkaline organosolv delignification: } \\
\text { a. } \mathrm{NaOH}-\mathrm{AQ}: 55.17 \mathrm{~g} / \mathrm{L} \mathrm{NaOH}, 140 \mathrm{~min}, 170^{\circ} \mathrm{C} \text {, LSR: } 5 / 1 \\
\text { b. } \mathrm{NaOH}-\mathrm{Ethanol}: 50 \mathrm{~g} / \mathrm{L} \mathrm{NaOH}, 35 / 65 \text { ethanol/water, } 60 \mathrm{~min}, 170^{\circ} \mathrm{C}, \mathrm{LSR}: 5 / 1 \\
\text { EH: Cellulase }\left(20 \mathrm{FPU} / \mathrm{g} \text { glucan) and } \beta \text {-glucosidase }(40 \mathrm{IU} / \mathrm{g} \text { glucan }), 50^{\circ} \mathrm{C}, 72 \mathrm{~h}\right.\end{array}$ & $\begin{array}{l}\text { a. } 96,9 \% \\
\text { b. } 91,1 \%\end{array}$ & Kruyeniski et al. (2016a) \\
\hline Pinus radiata & New Zealand & $\begin{array}{l}\text { Mechanical treatment: } \\
\text { 1. Thermomechanical stage: } 5 \text { min atmospheric steaming, } 80^{\circ} \mathrm{C}+1^{\text {st }} \\
\text { compression screw }(3: 1 \text { ratio })+72 \text { min steaming, } 7.5 \text { bar }\left(173^{\circ} \mathrm{C}\right)+2^{\text {nd }} \\
\text { compression screw } \\
\text { 2. Milling: pressurized disc-refining }+60 \text { min wet ball-milling } \\
\text { EH: Cellulase enzyme complex }(20 \mathrm{FPU} / \mathrm{g} \text { substrate }), 50^{\circ} \mathrm{C}, 24 \mathrm{~h}\end{array}$ & $1+2=80 \%$ & Suckling et al. (2017) \\
\hline $\begin{array}{l}\text { Pinus pseudostrobus } \\
\text { sawdust }\end{array}$ & Mexico & $\begin{array}{l}\text { Acid + alkaline treatments: } \\
\text { 1. Nitric acid: } 10.9 \% \mathrm{HNO}_{3} ; 30 \mathrm{~min} ; 114.8^{\circ} \mathrm{C} \\
\text { 2. Sodium hydroxide } 1 \% \mathrm{NaOH} \\
\text { EH: Cellulase enzyme complex ( } 25 \mathrm{FPU} / \mathrm{g} \text { of total carbohydrate), } 48^{\circ} \mathrm{C}, 72 \mathrm{~h}\end{array}$ & $\begin{array}{l}1 .+2 . \\
99.2 \% \text { reducing sugars/ cellulose in } \\
\text { the pretreated material }\end{array}$ & Farías-Sánchez et al. (2017) \\
\hline Pinus eldarica & Iran & $\begin{array}{l}\text { Mechanical treatment: Milling, particles less } 1 \mathrm{~mm} \\
\text { Dilute alkaline treatment: } 2 \%(\mathrm{w} / \mathrm{v}) \mathrm{NaOH}, 180^{\circ} \mathrm{C}, 5 \mathrm{~h} \\
\text { EH: Cellulase enzyme complex + hemicellulase, } 48^{\circ} \mathrm{C}, 72 \mathrm{~h}\end{array}$ & $78 \%$ & Safari et al. (2017) \\
\hline
\end{tabular}

EH: Enzymatic hydrolysis $\quad *$ As appears in the original reference.

Table 4.

Summary of eucalyptus pretreatments and their corresponding enzymatic digestibility.

\begin{tabular}{|c|c|c|c|c|}
\hline Raw material* & Origin & Pretreatments and conditions & $\begin{array}{l}\text { Maximum enzymatic } \\
\text { digestibility }\end{array}$ & Reference \\
\hline Eucalyptus globulus & Spain & $\begin{array}{l}\mathrm{HCl}-\text { catalysed acid delignification: } \\
70 \% \text { acetic acid, } 0.025 \% \mathrm{HCl}, 160^{\circ} \mathrm{C} ; 1 \mathrm{~h} \\
\mathrm{EH}: 50^{\circ} \mathrm{C}, 48 \mathrm{~h}\end{array}$ & $50 \%$ & Vazquez et al. (2000) \\
\hline $\begin{array}{l}\text { Six species, mainly } \\
\text { Eucalyptus globulus }\end{array}$ & Japan & $\begin{array}{l}\text { Acid catalyzed organosolv delignification: } \mathrm{EtOH} / \text { water: } 75 / 25,200^{\circ} \mathrm{C} \text {, } \\
60 \mathrm{~min}, 1 \mathrm{wt} . \% \text { acetic acid on liquor }+ \\
\text { Pulverization: ball milling } \\
\text { EH: } 50 \mathrm{mg} \text { of pretreated wood in } 17 \\
\mathrm{~mL} \text { of acetate buffer, } 2 \mathrm{mg} \text { enzyme, } 45^{\circ} \mathrm{C}, 48 \mathrm{~h}\end{array}$ & $100 \%$ & Teramoto et al. (2007) \\
\hline Eucalyptus & Japan & $\begin{array}{l}\text { Hot-compressed water }(\mathrm{HCW}): 160^{\circ} \mathrm{C}, 30 \mathrm{~min}+\text { Mechanical treatment: } \\
\text { ball milling } 20 \text { min. } \\
\text { EH: } 4 \text { FPU/g substrate, } 72 \mathrm{~h}, 45^{\circ} \mathrm{C}\end{array}$ & $\begin{array}{l}66.7 \% \text { (on sugar content in dried } \\
\text { eucalyptus) }\end{array}$ & Inoue et al. (2008) \\
\hline Eucalyptus globulus & Spain & $\begin{array}{l}\text { Hot water autohydrolysis: } \\
250^{\circ} \mathrm{C}(4.0 \mathrm{MPa}) \\
\text { EH: } 10,3 \mathrm{FPU} / \mathrm{g} \text { substrate and } 10 \beta \text {-glucosidase } 10 \mathrm{IU} / \mathrm{FPU}, 96 \mathrm{~h}, 48.5^{\circ} \mathrm{C}\end{array}$ & $\begin{array}{l}100 \% \text { cellulose-to-glucose conversion } \\
\text { (high degradation cellulose in the } \\
\text { pretreatment, } 79 \% \text { recovery) }\end{array}$ & Romaní et al. (2010) \\
\hline Eucalyptus globulus & Spain & $\begin{array}{l}\text { Hot water treatment: } 198^{\circ} \mathrm{C}+ \\
\text { Organosolv delignification: } 60 \mathrm{~kg} \text { ethanol/100 kg liquor; } \\
\text { LSR: } 8 \mathrm{~g} \text { liquor/g oven-dry autohydrolyzed wood; } 1 \mathrm{~h} \\
\text { EH: } 10.3 \mathrm{FPU} / \mathrm{g} \text { pretreated material, and } \\
\beta \text {-glucosidase/cellulase ratio }=5 \mathrm{IU} / \mathrm{FPU}, 48.5^{\circ} \mathrm{C}, 72 \mathrm{~h}\end{array}$ & $\begin{array}{l}100 \% \text { calculated (agree with } \\
\text { experiences) for So: } 3.65-3.94 \text { and } \mathrm{T} \text { : } \\
180-200^{\circ} \mathrm{C}\end{array}$ & Romaní et al. (2011) \\
\hline Eucalyptus globulus & Spain & $\begin{array}{l}\text { Water pre-extraction: immersion for } 16 \mathrm{~h} \text { at } 25^{\circ} \mathrm{C}+ \\
\text { Steam explosion: } 1.08 \mathrm{MPa}\left(183^{\circ} \mathrm{C}\right) \text {, Severity factor }=3.56 \text {, } \\
\text { two cycles: } 10 \mathrm{~min} \text { and } 3 \mathrm{~min}+\text { Laccase-mediator system }+ \text { Mechanical } \\
\text { treatment: milling to particles }<1 \mathrm{~mm} \text {. } \\
\text { EH: Cellulolytic complex } 20 \mathrm{EGU} / \mathrm{g}+\mathrm{b} \text {-glucosidase }\left(1: 3 \text { ratio), } 50^{\circ} \mathrm{C} \text {, }\right. \\
72 \mathrm{~h}\end{array}$ & $27.1 \%$ & $\begin{array}{l}\text { Martín-Sampedro et al. } \\
\text { (2012) }\end{array}$ \\
\hline Eucalyptus grandis & Korea & $\begin{array}{l}\text { Alkali catalyzed steam explosion: impregnation: } 7 \text { wt. } \% \mathrm{NaOH}+ \\
\text { Steam explosion: } 210^{\circ} \mathrm{C}, 9 \text { min. } \\
\text { EH: } 50^{\circ} \mathrm{C}, 72 \mathrm{~h}, 30 \mathrm{FPU} / \mathrm{g} \text { glucan }\end{array}$ & $65.5 \%$ glucose recovery & Park et al. (2012) \\
\hline
\end{tabular}

Please cite this article as: Vallejos M.E., Kruyeniski J., Area M.C. Second-generation bioethanol from industrial wood waste of South American species. Biofuel Research Journal 15 (2017) 654-667. DOI: 10.18331/BRJ2017.4.3.4 
Table 4.

(Continued).

\begin{tabular}{|c|c|c|c|c|}
\hline Raw material* & Origin & Pretreatments and conditions & $\begin{array}{l}\text { Maximum enzymatic } \\
\text { digestibility }\end{array}$ & Reference \\
\hline Eucalyptus globulus & Spain & $\begin{array}{l}\text { Hot water autohydrolysis: } \\
\mathrm{T}_{\max } 230^{\circ} \mathrm{C} . \\
\mathrm{EH}: 16 \mathrm{FPU} / \mathrm{g}, 35^{\circ} \mathrm{C}, 96 \mathrm{~h}\end{array}$ & $\begin{array}{l}\text { Maximum ethanol conversion in } \\
\text { SSF: } 91 \% ; 67.4 \mathrm{~g} / \mathrm{L}\end{array}$ & Romaní et al. (2012) \\
\hline Eucalyptus globulus & Chile & $\begin{array}{l}\text { Alkaline delignification: } \\
\text { Kraft pulping: } 155^{\circ} \mathrm{C}, 20 \% \mathrm{AA}, 30 \mathrm{~min} \\
\mathrm{EH}: 20 \mathrm{FPU} \text { and } 40 \mathrm{IU} / \mathrm{g} \text { of pretreated material, } 50^{\circ} \mathrm{C}, 96 \mathrm{~h}\end{array}$ & Glucans conversion $100 \%$ & Monrroy et al. (2012) \\
\hline Eucalyptus dunniithinnings & Australia & $\begin{array}{l}\text { Mechanical treatment: milling (particle size } 1.0 \mathrm{~mm}-1.4 \mathrm{~mm})+ \\
\text { Soaking in acid: } 0.5 \% \mathrm{H}_{2} \mathrm{SO}_{4}(\mathrm{v} / \mathrm{v}), 60 \mathrm{~min} \text {, room temperature + } \\
\text { Microwave treatment: } 195^{\circ} \mathrm{C} ; 7 \mathrm{~min} \\
\text { EH: dosed } 1.25 \% \text { (protein n cellulose), } 50^{\circ} \mathrm{C}, 48 \mathrm{~h}\end{array}$ & $\begin{array}{l}74 \% \text { conversion of theoretical } \\
\text { cellulose }\end{array}$ & McIntosh et al. (2012) \\
\hline $\begin{array}{l}\text { Eucalyptus nitens }(\mathrm{EN}) \\
\text { E. globulus }(\mathrm{GLO}) \\
\text { E. urograndis }(\mathrm{URO})\end{array}$ & USA & $\begin{array}{l}\text { Alkaline delignification: } \\
\text { Kraft pulping: } 150^{\circ} \mathrm{C}, 10: 1 \text { liquor:wood, } 40 \% \mathrm{AA}, 25 \% \text { sulfidity, } 60 \mathrm{~min} \\
\mathrm{EH} \text { : Cellulase and } \beta \text {-glucosidase, } 20 \mathrm{FPU} / \mathrm{g} \text { on dry weight of the substrate, } \\
50^{\circ} \mathrm{C}, 48 \mathrm{~h}\end{array}$ & $\begin{array}{l}94.7 \%(\mathrm{EN}) \\
97.9 \%(\mathrm{GLO}) \\
80.2 \%(\mathrm{URO})\end{array}$ & Santos et al. (2012) \\
\hline Eucalyptus & China & $\begin{array}{l}\text { Dilute acid treatment } \\
160^{\circ} \mathrm{C}, 0.75 \% \mathrm{SO}_{4} \mathrm{H}_{2}, 10 \mathrm{~min} \\
\text { EH: } 20 \mathrm{FPU} / \mathrm{g} \text { dry matter, } 50^{\circ} \mathrm{C}, 60 \mathrm{~h}\end{array}$ & $32.19 \%$ Glucose & Wei et al. (2012) \\
\hline Eucalyptus globulus & Spain & $\begin{array}{l}\text { Four cycles: } M \text {. thermophila laccase }(50 \mathrm{U} / \mathrm{g}) \text { - mediator methyl syringate } \\
(3 \%)+\text { Peroxide-reinforced alkaline extraction: } 1 \% \text { (w:w) } \mathrm{NaOH} \text {, } \\
3 \% \text { (w:w) } \mathrm{H}_{2} \mathrm{O}_{2} \text { (odw), } 80^{\circ} \mathrm{C}, 90 \mathrm{~min} \\
\text { EH: Cellulase }\left(2 \mathrm{FPU} / \mathrm{g} \text { ) and } \beta \text {-glucosidase }(100 \mathrm{nkat} / \mathrm{g}), 45^{\circ} \mathrm{C}, 72 \mathrm{~h}\right.\end{array}$ & $55.7 \%$ (glucose/sample weight) & Rico et al. (2014) \\
\hline
\end{tabular}

$\begin{array}{ll} & \text { Mechanical treatment: milling + pulverizing to particles }<0.2 \mathrm{~mm}+ \\ \text { Eucalyptus } & \text { Hot water autohydrolysis: } 150^{\circ} \mathrm{C}, 4 \mathrm{~h} \\ & \text { EH: High solid saccharification }(32 \%), 0.04 \mathrm{~mL} \text { Optimash BG/g of dry } \\ & \text { substrate, } 24 \mathrm{~h}\end{array}$

$76 \%$ glucose yield based on the sugar content in the pretreated Fujii et al. (2014)
sample

\begin{tabular}{lll}
\hline & Biological pretreatment: white-rot fungi: Pleurotusostreatus \\
Eucalyptus grandis sawdust & Brazil & EH: Cellulase (from $T$. Reesei added to obtain a final activity of $10 \mathrm{U} / \mathrm{mL}), 48.0 \mu \mathrm{mol}$ reducing sugars $/ \mathrm{mL} \quad$ Castoldi et al. (2014) \\
& $37^{\circ} \mathrm{C}, 48 \mathrm{~h}$ \\
\hline
\end{tabular}

Eucalyptus urophylla Hot water pretreatment: $240^{\circ} \mathrm{C} ; 30 \mathrm{~min}+$

\begin{tabular}{ll} 
Eucalyptus urophylla $\quad$ China & Alkaline fractionation: $2 \% \mathrm{NaOH} ; 90^{\circ} \mathrm{C} ; 2.5 \mathrm{~h}$ \\
& $\mathrm{EH}: 17 \mathrm{FPU} / \mathrm{g}$ and $34 \mathrm{IU} / \mathrm{g}$ dry weight of substrate, $50^{\circ} \mathrm{C}, 72 \mathrm{~h}$ \\
\hline
\end{tabular}

95.6\% Sun et al. (2014)

\begin{tabular}{|c|c|c|c|c|}
\hline Eucalyptus grandis & Australia & $\begin{array}{l}\text { Diluted acid: } \\
\text { a. } 4.8 \text { wt. } \% \mathrm{H}_{2} \mathrm{SO}_{4} ; 190^{\circ} \mathrm{C} ; 15 \mathrm{~min} \\
\text { b. } 2.4 \mathrm{wt} \% \mathrm{H}_{2} \mathrm{SO}_{4} ; 180^{\circ} \mathrm{C} ; 15 \mathrm{~min} \\
+ \\
\text { Steam explosion (pilot-scale) } \\
\text { EH: } 20 \mathrm{FPU} / \mathrm{g} \text { glucan, } 50^{\circ} \mathrm{C}, 72 \mathrm{~h}\end{array}$ & $\begin{array}{l}\text { a. } 68.0 \% \\
\text { b. } 71.8 \%\end{array}$ & McIntosh et al. (2016) \\
\hline Eucalyptus globulus L. & Chile & $\begin{array}{l}\text { Mechanical treatment: } 0.5-1 \mathrm{~mm} \times 0.5-1 \mathrm{~mm} \text { high } \times 10-20 \mathrm{~mm}+ \\
\text { Ionic liquid: } 1-\mathrm{N} \text {-ethyl-3-methylimidazolium acetate }(\mathrm{C} 2 \mathrm{minOAc}), 1: 3 \\
\text { wtwood:wt IL; } 150^{\circ} \mathrm{C} \\
\text { a) } 30 \mathrm{~min} \\
\text { b) } 60 \mathrm{~min} \\
\text { EH: } 37 \mathrm{FPU} / \mathrm{g} \text { cellulose and } 4.9 \mathrm{CBU} / \mathrm{g} \text { cellulose, } 50^{\circ} \mathrm{C}, 72 \mathrm{~h}\end{array}$ & $\begin{array}{l}\text { Sugar yield (theoretical value } \\
\text { of carbohydrate in biomass, wt- } \\
\% \text { ): } \\
\text { a. } 65.8 \\
\text { b. } 82.2\end{array}$ & Lienqueo et al. (2016) \\
\hline $\begin{array}{l}\text { Eucalyptus urophylla } x E \text {. } \\
\text { grandis }\end{array}$ & Brazil & $\begin{array}{l}\text { Alkaline pretreatment: } 10 \% \mathrm{NaOH} \text { (o.d.); liquor:biomass }=2: 1 ; 175^{\circ} \mathrm{C} \text {; } \\
90 \text { min to } \mathrm{T}_{\max } ; 15 \mathrm{~min} \text { at } \mathrm{T}_{\max } ; \mathrm{H} \text { factor }=628 \\
\text { Mechanical treatment: milling to } 20 / 80 \text { mesh size } \\
\text { EH: } 15 \mathrm{FPU} / \mathrm{g} \text { substrate } 50^{\circ} \mathrm{C}, 72 \mathrm{~h}\end{array}$ & $0.18 \mathrm{~g}$ glucose $/ \mathrm{g}$ biomass & de Carvalho et al. (2016) \\
\hline $\begin{array}{l}\text { Eucalyptus grandis } \times E \text {. } \\
\text { urophylla }\end{array}$ & China & $\begin{array}{l}\text { Mechanical treatment: } 80-100 \mathrm{mesh}+\text { Solvent extraction: } \\
\text { methylbenzene-ethanol, } 2: 1 \mathrm{v} / \mathrm{v}, 6 \mathrm{~h}+\text { Ionic liquid: } 1 \text {-butyl-3- } \\
\text { methylimidazolium acetate }([\mathrm{Bmim}] \mathrm{OAc}) \\
\text { Alkali treatment: } 4.0 \% \mathrm{NaOH}, 90^{\circ} \mathrm{C}, 2 \mathrm{~h}, 1: 20(\mathrm{~g} / \mathrm{mL}) \\
\text { EH: } 15 \mathrm{FPU} / \mathrm{g} \text { substrate, } 50^{\circ} \mathrm{C}, 72 \mathrm{~h}\end{array}$ & $\begin{array}{l}\text { [Bmim]OAc: } 62.6 \% \\
{[\text { Bmim]OAc + alkali treatment: }} \\
90.5 \%\end{array}$ & Li et al. (2016) \\
\hline
\end{tabular}

EH: Enzymatic hydrolysis ; T: Temperature ; So: Severity factor

$*$ As appears in the original reference

Please cite this article as: Vallejos M.E., Kruyeniski J., Area M.C. Second-generation bioethanol from industrial wood waste of South American species.

Biofuel Research Journal 15 (2017) 654-667. DOI: 10.18331/BRJ2017.4.3.4 
sawdust of regionally-growing species are unanimous in stressing on the need for conditions adjustment for any of these raw materials (Stoffel et al., 2014; Rangel et al., 2016).

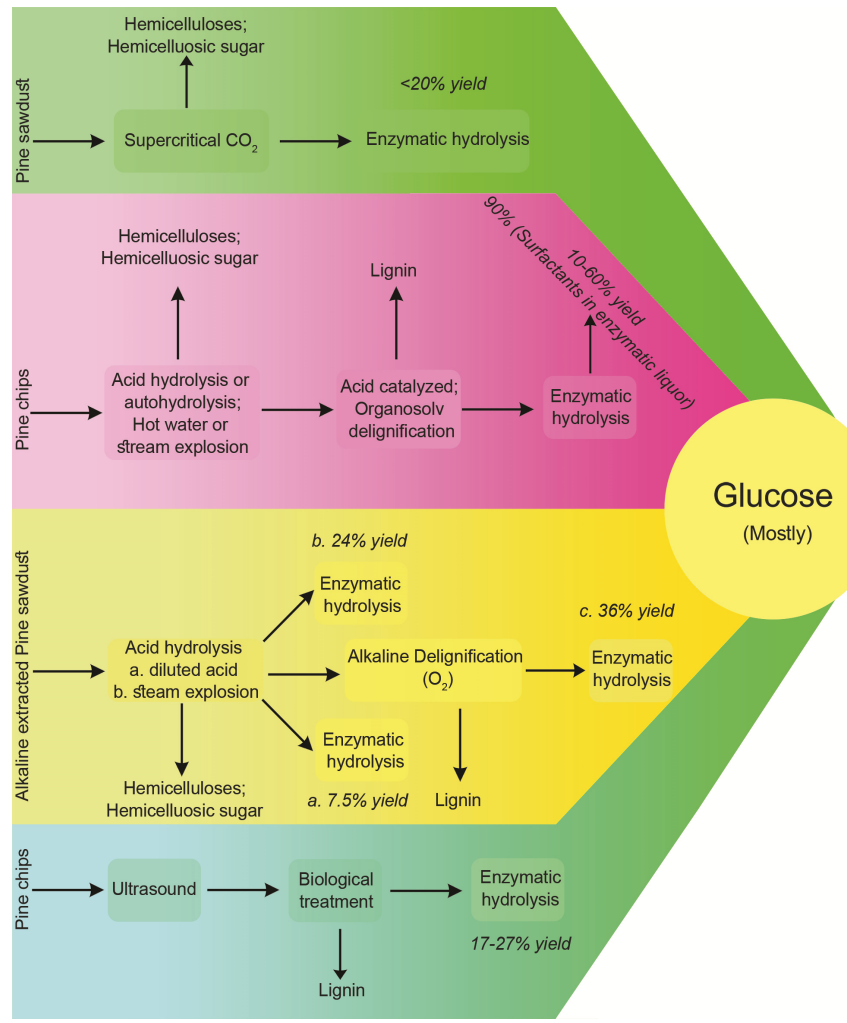

Fig.2. Schematic representation of reported pretreatments on pine producing low enzymatic hydrolysis yields.

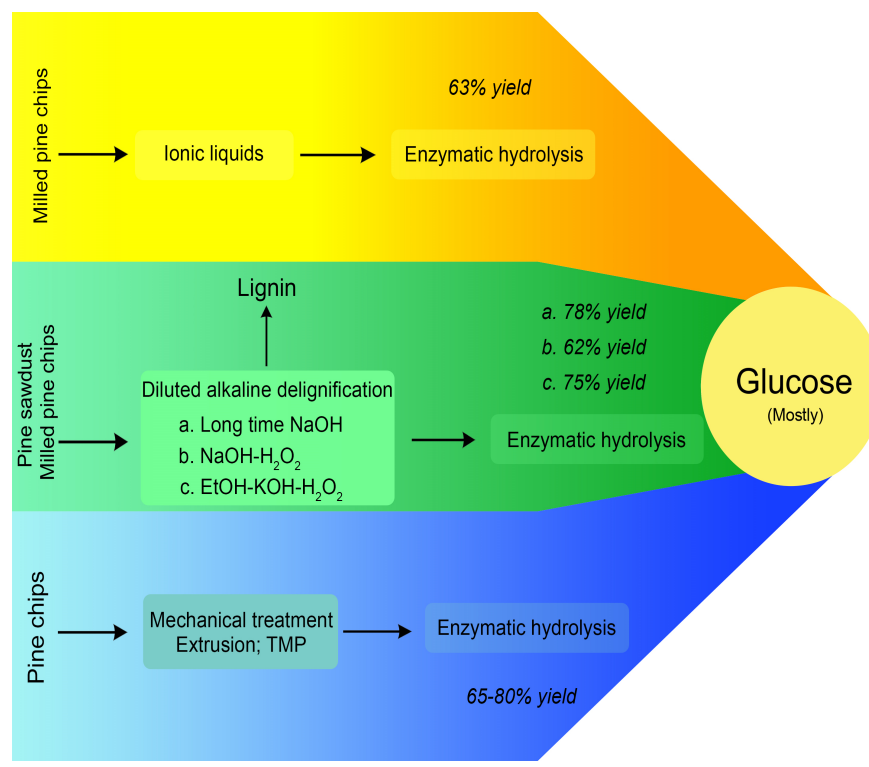

Fig.3. Schematic representation of reported pretreatments on pine producing medium enzymatic hydrolysis yields.

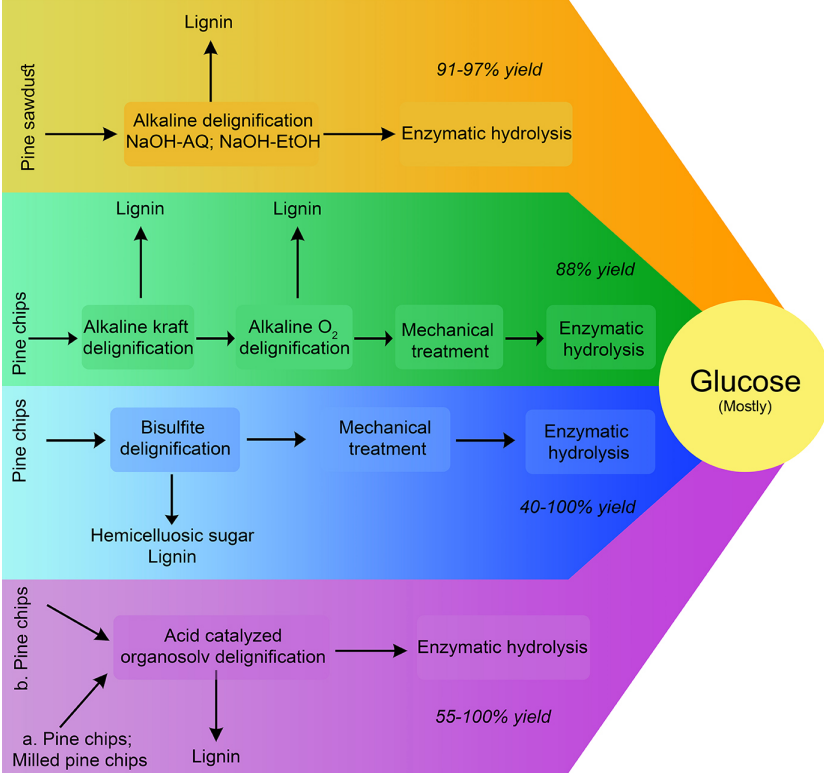

Fig.4. Schematic representation of reported pretreatments on pine producing high enzymatic hydrolysis yields.

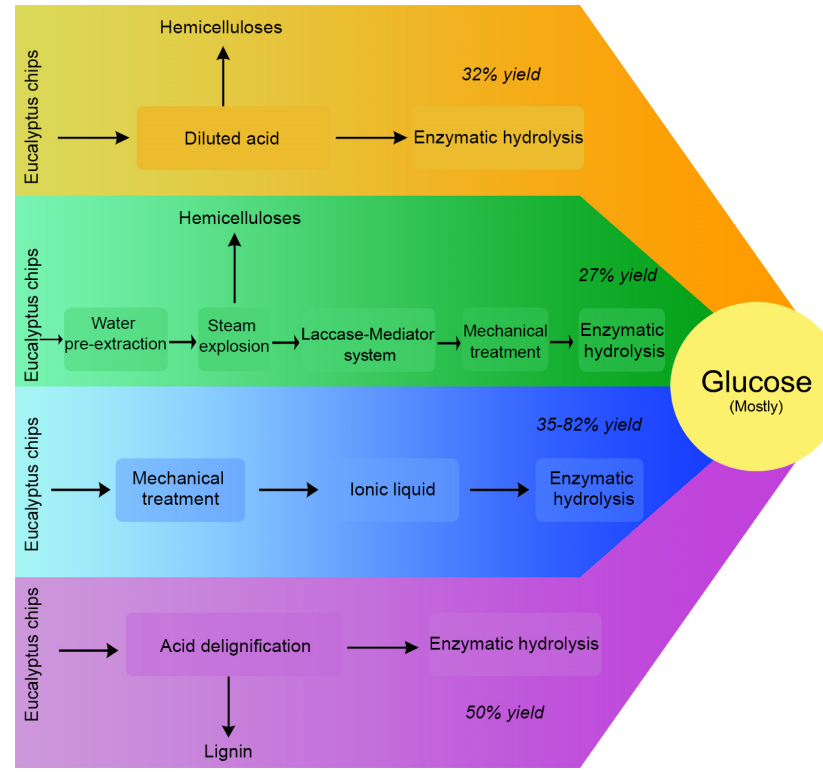

Fig.5. Schematic representation of reported pretreatments on eucalyptus producing low enzymatic hydrolysis yields.

Ethanol yields are usually expressed in comparison with the theoretical yield, i.e., $0.511 \mathrm{~g}$ of ethanol/g hexose. Like in the case of the $\mathrm{EH}$, ethanol yields are influenced by the raw material, the pretreatment, and the fermentation process, which can be Separate Hydrolysis and Fermentation (SHF) or Simultaneous Saccharification and Fermentation (SSF). In several cases, it is also necessary to apply a detoxification process to eliminate 


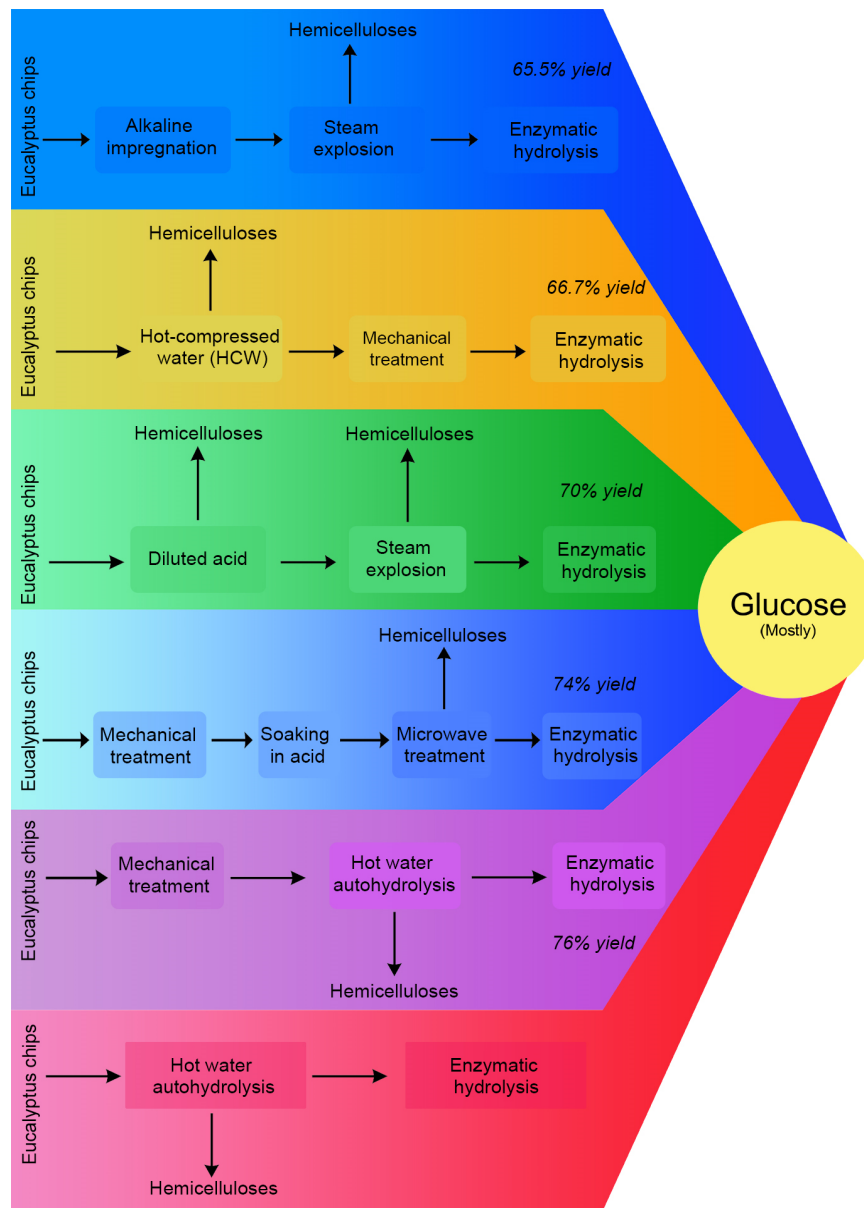

Fig.6. Schematic representation of reported pretreatments on eucalyptus producing medium enzymatic hydrolysis yields.

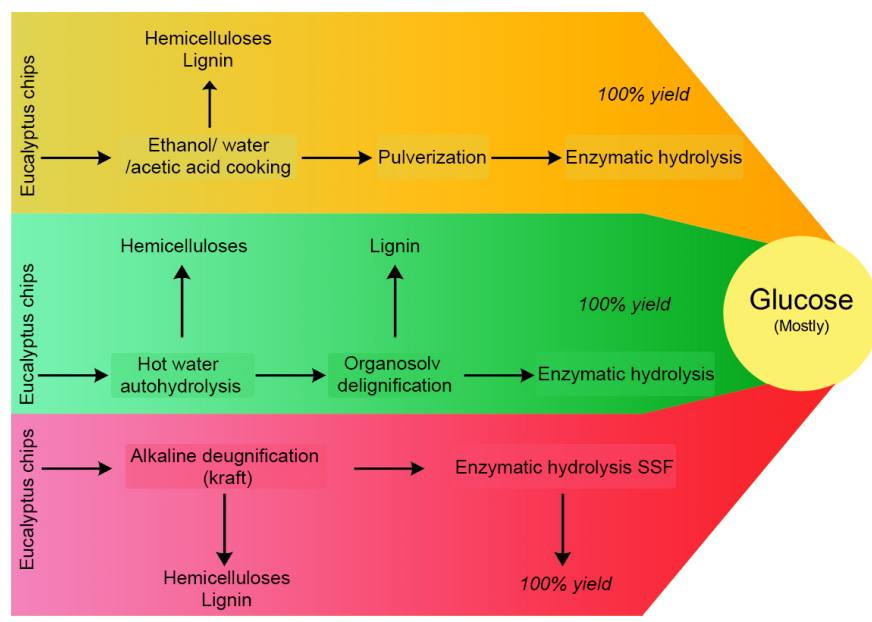

Fig.7. Schematic representation of reported pretreatments on eucalyptus producing high enzymatic hydrolysis yields. fermentation inhibitors such as 5-hydromethyl-furfural (HMF), furfural, or acetic acid among others (Hahn-Hägerdal et al., 2006). Reported ethanol yields obtained from pretreated pines with methods resulting in low to medium saccharification (Table 3 and Figures 2 and 3 ) were generally low, in the range of $28 \%$ (Bahmani et al., 2016) to $46.6 \%$ (Tain et al., 2016) using an SHF process. On the contrary, delignified materials present high ethanol yields, either using SHF or SSF, for example, $80.42 \%$ with an SSF process (Valenzuela et al., 2016), 88\% with an SHF (Fárias-Sánchez et al., 2017), and about 90\% applying an SHF process (Kruyeniski et al., 2016b). Ethanol yields in the case of eucalyptus are usually high, without differences among materials subjected to acid hydrolysis or delignification. Based on the data reported in the selected works tabulated in Table 4, an ethanol yield of $86.4 \%$ was obtained by the SSF of a hydro-thermally pretreated material at $230^{\circ} \mathrm{C}$ (Romaní et al., 2010) and $92 \%$ was obtained with an SHF process using a material pretreated by diluted acid (McIntosh et al., 2012). Furthermore, the ethanol yield of the SSF of a kraft pulp was 96\% (Monrroy et al., 2012) while that of an organosolv-pretreated pulp stood at $91.1 \%$ (Romaní et al., 2011). Nevertheless, the ethanol yield of the SSF of wood pretreated by an ionic liquid resulted in only $38 \%$ (Lienqueo et al., 2015), while that of the pre-saccharification simultaneous saccharification fermentation (PSSF) of eucalyptus wood pretreated by diluted acid and steam explosion at pilot scale was $42 \%$ (McIntosh et al., 2016). This conforms that certain pretreatments lead to physicochemical changes in the materials used which may not be positive for the EH nor for fermentation.

\section{Technical and economic aspects of bioethanol production}

As mentioned earlier, second-generation bioethanol is still under development at pilot and pre-commercial scales. In better words, its economic feasibility at large scale has not yet been justified because of its high costs, which are two to three times more expensive than petroleum fuels considering an equivalent energy basis ( Lynd et al., 2005; Carriquiry et al., 2011; van Eijck et al., 2014; Achinas and Euverink, 2016). Nevertheless, the production cost can be decreased by: (i) improvement in feedstock production and logistics, (ii) increase in energy efficiency of the processes involved (i.e., pretreatment, saccharification, and fermentation) and (iii) the production of multiple products (Carriquiry et al., 2011; Melin et al., 2011). On the other hand, in most cases, energy cost determines the global process cost. Therefore, energy savings by optimizing the operating conditions of the different systems are essential to increase profit margin and reduce emissions (Kemp, 2007).

Overall, developing suitable pretreatments to minimize energy consumption and to improve enzymatic saccharification and fermentation are key to achieve high sugars and ethanol yields. Any given pretreatment process can be evaluated through its energy efficiency and the attainable sugars yield (Zhu and Pan, 2010; Walker, 2011; Kang et al., 2014). In biorefineries, the pretreatments implemented could affect the downstream processes, the scale-up, and the technological scheme. The type of pretreatment could also determine the chemical recovery processes and the wastewater treatment. In general, scale-up is a technological challenge that involves high capital investments, as well as detailed research and development (Naik et al., 2010; Aditiya et al., 2016; Muktham et al., 2016).

As mentioned in the previous section, size reduction (increasing surface area) of wood chips by milling could improve the enzyme accessibility to cellulose. Unlike agricultural wastes, wood chips milling requires high electric-mechanical energy, approximately 500 to $800 \mathrm{kWh} /$ ton, which is equivalent to $25-40 \%$ of the thermal energy produced by the ethanol. Therefore, pretreatments that need a prior size reduction, e.g., those with ionic liquids (IL), should take into account this energy demand (Zhu et al., 2010). An alternative to size reduction is the use as feedstock of sawmills wastes such as sawdust because these lignocellulosic materials do not require size reduction.

On the other hand, by performing size reduction of wood chips after chemical treatment, an energy savings of about $80 \%$ could be achieved. So the cellulosic pulping industry has a high potential for bioethanol production, and its treatments, processes, and equipment are technologically exchangeable. Other benefits of size reduction after a chemical treatment are a better separation of the pretreated solids from the liquid, energy savings in mixing with respect to the pretreatment of 
fiberized or pulverized materials, and a reduction of thermal energy in the chemical treatment due to the use of low liquid-to-solid ratios (LSR). Fiberized materials require high LSR because they have much more water intake than wood chips, and consequently, they need a greater thermal energy for heating up the water or liquor (Zhu et al., 2010; Vallejos et al., 2012, 2015 and 2017).

Temperature and LSR mainly govern the thermal energy consumption in chemical pretreatments, so the reduction of these parameters is critical for the increase of their energy efficiency (Balan, 2014; Kang et al., 2014). The pretreatments with $\mathrm{IL}$ are carried out at temperatures below $100^{\circ} \mathrm{C}$ but require LSR of 10 to 20 (Tian et al., 2016). Although the temperature is low, high LSRs increase the thermal energy consumption to values greater than the thermal energy of aqueous thermochemical pretreatments. For example, the required energy at $75^{\circ} \mathrm{C}$ and LSR of 10 is $18 \%$ more than that required at $180^{\circ} \mathrm{C}$ and LSR of 3 (Zhu et al., 2010). The performance of different pretreatments at varied LSR was studied in several works (Saska and Ozer, 1995; Garrote et al., 2003; Carvalheiro et al., 2004 and 2008; Chen et al., 2010; Rangel et al., 2016; Testova et al., 2009; Vallejos et al., 2012 and 2015).

The production of multiple products is key to have competitive production cost against the first-generation biofuels and that depends on the pretreatment processes. Several high-value products can be produced through the secondgeneration biorefineries to reduce the overall processing cost of biofuels (Stephen et al., 2012; Balan, 2014). Lignin is an aromatic polymer usually used in the pulp and paper industry to generate energy (heat and power). Regional pines can be a valuable source of vanillin, which is produced from lignin at large commercial scale and competes with vanillin based on guaiacol derived from petroleum (Pinto et al., 2013). On a smaller scale, bakelite, resins, and plastic filler materials can also be produced and new byproducts will surely be obtained from lignin based on catalytic processes in the following years. The type of recovered lignin depends on the treatments used to remove it from the biomass. For example, high purity isolated organosolv lignin can be used for producing high valued byproducts (Hubbe, 2015). Isolated lignin from a steam explosion or dilute acid pretreatments is highly condensed and can be used for energy generation through producing products like pellets or brickets (Stephen et al., 2012).

Important aspects to take into account when starting a business of this type are the costs of feedstock, enzymes, and capital since they are crucial in defining the costs of second-generation bioethanol. According to a calculation made in the year 2016, the contributions of the costs of each one of these factors to bioethanol production cost was USD $0.26 / \mathrm{L}$ for feedstock, USD $0.26-0.40 / \mathrm{L}$ for enzymes, and USD 1.85/L for capital investment, including on-site enzyme production (Araújo, 2016).

Bioethanol production costs depend on the biomass source and only a few kinds of biomass having prices close to fossil fuels can be competitive. For bioethanol to compete economically with petrol, production costs should be no greater than EUR 0.2/L approximately. Some bioethanol production costs from wood are EUR $0.44-0.63 / \mathrm{L}$ for spruce (softwood), EUR $0.48-0.71 / \mathrm{L}$ for willow (hardwood), and EUR 0.11 - 0.32/L for wood wastes (Walker, 2011). The great advantage of using low-cost sawing waste is accordingly very clear.

Estimations for Brazil in the year 2020 show that eucalyptus production costs, specifically as raw material for bioethanol, will be 2.4-3.3 USD/GJ generated, involving mainly fertilizers and harvesting costs. The technological scheme proposes a pretreatment sequence including mechanical and acid treatments followed by enzymatic saccharification of the residual solids and fermentation of sugars. The investment costs for a capacity of $400 \mathrm{MWth}$ would be USD 374 million (van Eijck et al., 2014).

Moreover, a techno-economic analysis on the production of secondgeneration bioethanol concluded that high-performance enzymes at a price less than USD 18.2/L of ethanol would be required and that higher ethanol concentration in the fermentor would be needed to be competitive (Kazi et al., 2010). The reduction in the hydrolysis time while maintaining the same yield would could also result in a reduction of capital cost. Improvements could also be achieve through the implementation of the SSF. Further research is still needed in this domain to achieved significantly higher level of optimization of the processes involved.

Energy integration, chemicals recovery, higher capacities, and integration of the ethanol plant with already existing facilities, could also reduce the ethanol production cost (Von Sivers and Zacchi, 1995). As examples, the combination of enzymes recycling and decreases in hydrolysis time led to decreased ethanol production cost by $27 \%$ for hardwoods and $38 \%$ for softwood feedstocks (Gregg et al., 1998). The co-location of the bioethanol plant into a softwood kraft-pulping mill, using the kraft process plus oxygen delignification as pretreatment were also shown to result in economic production of bioethanol (Wu et al., 2014). More specifically, an economic analysis showed that through such implementations, an ethanol yield of $285 \mathrm{~L} / \mathrm{ton}$ of dry wood with a total production cost of USD $0.55 / \mathrm{L}$ could be obtained (Wu et al., 2014). In this sense, it would be interesting to evaluate how the incorporation of a different pretreatment to a different raw material (like pin-chips or sawdust) would work, taking advantage of the existing infrastructure of the mill.

\section{Conclusions}

Eucalyptus and pines are the most important woody raw materials in South America. Most processes applied as pretreatments to pine begin with a reduction in the size of the materials by grinding, except in the case of delignifying processes that, in general, work directly with chips. Treatments with diluted acid, steam explosion or supercritical $\mathrm{CO}_{2}$, aimed at the extraction of hemicelluloses, slightly affect the digestibility of the material If acid-treated pine wood is delignified, the yields of $\mathrm{EH}$ increase but to a less extent than when the delignification treatments are applied to the untreated materials. Materials treated under mild conditions (slightly acidic or alkaline processes, including organosolv delignification), generally have lower EH yields than either medium or highly alkaline treatments. The above are conclusions generally drawn, a few cases have been mentioned in which treatments with diluted acids and diluted alkalis led to high EH yields though. This could be ascribed to the variations in the materials used affecting the subsequent delignification or in better words, to the particular characteristics of the raw materials (pine).

Eucalyptus wood is less recalcitrant to $\mathrm{EH}$ than pine wood, so autohydrolysis and alkaline pretreatments are effective options. Novel and more complex treatments or treatment combinations are being studied, but $\mathrm{EH}$ yields do not exceed that of alkaline delignification.

Like in the case of the EH, ethanol yields are influenced by the raw materials, the pretreatment, and the fermentation process. The differences between pines and eucalyptus observed in the $\mathrm{EH}$ are reflected in the yields of ethanol obtainable from pretreated materials.

Overall, the success of the second-generation bioethanol depends on its technical, environmental, and economic feasibility. The price of the lignocellulosic raw material is one of the most important items in the cost distribution of second-generation bioethanol, whence it is clear the great advantage of using low-cost sawing waste. Biorefineries can also contribute to the reduction of the overall processing cost of bioethanol production by processing wood wastes, using energy and cost-effective technologies, and simultaneous production of high added-value products.

Second-generation bioethanol could generally be regraded as a viable option to valorize the residues of the forest industry in South America. This could be well explained by the highly economically available and unexploited wood residues generated by the fast-growing plantations in Argentina, Brazil, Chile, and Uruguay on one hand and the growing interest in further development of renewable energies in the region on the ither hand.

\section{References}

[1] Achinas, S., Euverink, G.J.W., 2016. Consolidated briefing of biochemical ethanol production from lignocellulosic biomass. Electron. J. Biotechnol. 23, 44-53

[2] Aditiya, H.B., Mahlia, T.M.I., Chong, W.T., Nur, H., Sebayang, A.H., 2016. Second generation bioethanol production: a critical review. Renew. Sust. Energy Rev. 66, 631-653.

[3] Alvarez-Vasco, C., Zhang, X., 2017. Alkaline hydrogen peroxide (AHP) pretreatment of softwood: enhanced enzymatic hydrolysability at low peroxide loadings. Biomass Bioenergy. 96, 96-102.

[4] Alvira, P., Tomás-Pejó, E., Ballesteros, M.J., Negro, M.J., 2010. Pretreatment technologies for an efficient bioethanol production process based on enzymatic hydrolysis: a review. Bioresour. Technol. 101(13), 4851-4861

[5] Amiri, H., Karimi, K., 2016. Integration of autohydrolysis and organosolv delignification for efficient acetone, butanol, and ethano. 
production and lignin recovery. Ind. Eng. Chem. Res. 55(17), 4836-4845.

[6] Araújo, W.A., 2016. Ethanol industry: surpassing uncertainties and looking forward, in: Monteiro Salles-Filho, S.L., Barbosa Cortez, L.A., Ferreira Jardim da Silveira, J.M., Trindade, S. (Eds.), Global Bioethanol. Evolution, Risks, and Uncertainties. Academic Press, pp. 1-33.

[7] Area, M.C., Popa, V., 2014. Wood Fibres for Papermaking, first ed. Smithers Pira Limited, Shawbury, Shropshire, UK.

[8] Area, M.C., Vallejos, M.E., 2012. La biorrefinería forestal, in: Area, M.C., Vallejos, M.E. (Eds.), Biorrefinería a Partir de Residuos Lignocelulósicos. Conversión de Residuos a Productos de Alto Valor. Editorial Académica Española, Saarbrücken, Germany, pp. 1-20.

[9] Bahmani, M.A., Shafiei, M., Karimi, K., 2016. Anaerobic digestion as a pretreatment to enhance ethanol yield from lignocelluloses. Process Biochem. 51(9), 1256-1263.

[10] Balan, V., 2014. Current challenges in commercially producing biofuels from lignocellulosic biomass. ISRN Biotechnol. 1-31.

[11] Bengoechea, D.I., Stoffel, R.B., Area, M.C., 2012. Pretratamientos o fraccionamientos, in: Area, M.C., Vallejos, M.E. (Eds.), Biorrefinería a Partir de Residuos Lignocelulósicos. Conversión de Residuos a Productos de Alto Valor. Editorial Académica Española, Saarbrücken, Germany, pp. 109-150.

[12] Berg, A., Segura, C., 2016. Biomass as an energy source in Chile, in: Proceedings of the 59th International Convention of Society of Wood Science and Technology. Curitiba, Brazil.

[13] Bertran, J., Morales, E., 2008. Potencial de Generación de Energía por Residuos del Manejo Forestal en Chile. Comisión Nacional de Energía (CNE)/Deutsche Gesellschaft für Technische Zusammenarbeit (GTZ) $\mathrm{GmbH}$. Santiago, Chile.

[14] Berrocal, A., Baeza, J., Rodríguez, J., Espinosa, M., Freer, J., 2004. Effect of tree age on variation of Pinus radiata D. Don chemical composition. J. Chil. Chem. Soc. 49(3), 251-256.

[15] Biobutanol, E.B.T.P., 2009. Biofuels policy and legislation. Eur. Biofuels Technol. Platf.

[16] Biofuels-Digest, 2016. Biofuels mandates around the world: 2016.

[17] Boscana, M., Boragno, L., 2016. Cadena forestal: el desafío del crecimiento sostenible. Report of the oficina de programación y políticas agropecuarias. Montevideo, Uruguay.

[18] Brodin, M., Vallejos, M., Tanase Opedal, M., Area, M.C., ChingaCarrasco, G., 2017. Lignocellulosics as sustainable resources for production of bioplastics-a review. J. Cleaner Prod. 162, 646-664.

[19] Carpineti, L.A., 1995. Manual Para Productores de Eucaliptos de la Mesopotamia Argentina. Instituto Nacional de Tecnología Agropecuaria.

[20] Carriquiry, M.A., Du, X., Timilsina, G.R., 2011. Second generation biofuels: economics and policies. Energy Policy. 39(7), 4222-4234.

[21] Carvalheiro, F., Duarte, L.C., Gírio, F.M., 2008. Hemicellulose biorefineries: a review on biomass pretreatments. J. Sci. Ind. Res. 67, 849864.

[22] Carvalheiro, F., Esteves, M.P., Parajó, J.C., Pereira, H., Gírio, F.M., 2004. Production of oligosaccharides by autohydrolysis of brewery's spent grain. Bioresour. Technol. 91(1), 93-100.

[23] Cassuto, D.N., Gueiros, C., 2013. The Evolution of the Brazilian Regulation of Ethanol and Possible Lessons for the United State.

[24] Castoldi, R., Bracht, A., de Morais, G.R., Baesso, M.L., Correa, R.C.G., Peralta, R.A., Moreira, R.D.F.P.M., de Moraes, M.D.L.T., de Souza, C.G.M., Peralta, R.M., 2014. Biological pretreatment of Eucalyptus grandis sawdust with white-rot fungi: study of degradation patterns and saccharification kinetics. Chem. Eng. J. 258, 240-246.

[25] Castro, C.A.D.O., Resende, R.T., Bhering, L.L., Cruz, C.D., 2016. Brief history of Eucalyptus breeding in Brazil under perspective of biometric advances. Ciência Rural. 46(9), 1585-1593.

[26] Chan, E.S., Rudravaram, R., Narasu, M.L., Rao, L.V., Ravindra, P., 2007. Economics and environmental impact of bioethanol production technologies: an appraisal. Biotechnol. Mol. Biol. Rev. 2(1), 14-32.

[27] Chandel, A.K., Chen, X., Lawoko, M., Heiningen, A., 2010. Kinetics and mechanism of autohydrolysis of hardwoods. Bioresour. Technol. 101(20), 7812-7819.

[28] CONAF, 2011. Plantaciones forestales.

[29] Cremonez, P.A., Feroldi, M., Feiden, A., Gustavo Teleken, J.G., José Gris, D.J., Dieter, J., de Rossi, E., Antonelli, J., 2015. Current scenario and prospects of use of liquid biofuels in South America. Renew. Sust. Energy Rev. 43, 352-362.

[30] de Carvalho, D.M., de Queiroz, J.H., Colodette, J.L., 2016 Assessment of alkaline pretreatment for the production of bioethanol from eucalyptus, sugarcane bagasse and sugarcane straw. Ind. Crops Prod. 94, 932-941

[31] Diputados, Senado y Cámara de Argentina, 2006. Ley 26.093. Régimen de regulación y promoción para la producción y uso sustentables de biocombustibles.

[32] Duffield, J.A., Johansson, R., Meyer, S., 2015. U.S. ethanol: an examination of policy, production, use, distribution, and market interactions

[33] Eisentraut, A., 2010. Sustainable production of second-generation biofuels. Potential and perspectives in major economies and developing countries. Int. Energy Agency (iea).

[34] FAO, 2015. Wood production sees growth driven by housing and green energy markets.

[35] Fardim, P., Durán, N., 2004. Retention of cellulose, xylan and lignin in kraft pulping of eucalyptus studied by multivariate data analysis: influences on physicochemical and mechanical properties of pulp. J. Braz. Chem. Soc. 15(4), 514-522.

[36] Fujii, T., Murakami, K., Endo, T., Fujimoto, S., Minowa, T. Matsushika, A., Yano, S., Sawayama, S., 2014. Bench-scale bioethanol production from eucalyptus by high solid saccharification and glucose/xylose fermentation method. Bioprocess Biosyst. Eng. 37(4), 749-754.

[37] Galbe, M., Zacchi, G., 2002. A review of the production of ethanol from softwood. Appl. Microbiol. Biotechnol. 59(6), 618-628

[38] García, A.E., Carmona, R.J., Lienqueo, M.E., Salazar, O., 2011. The current status of liquid biofuels in Chile. Energy. 36(4), 2077-2084.

[39] Garrote, G., Eugenio, M.E., Díaz, M.J., Ariza, J., López, F., 2003. Hydrothermal and pulp processing of Eucalyptus. Bioresour. Technol. 88(1), 61-68.

[40] González, J., García, A., 2015. Availability of forest biomass in Chile for second generation biodiesel production. Int. Congr. Energy Environ. Eng. Manage.

[41] González, J.R.Q., González, L.E.Q., 2015. Prospects of the potential of biomass energy in the global and Latin American framework. Gestión y Ambient. 18(1), 179-188.

[42] Gonzalez, R.W., Treasure, T., Phillips, R.B., Jameel, H., Saloni, D. 2011. Economics of cellulosic ethanol production: green liquor pretreatment for softwood and hardwood, greenfield and repurpose scenarios. BioResources. 6(3), 2551-2567.

[43] Gregg, D.J., Boussaid, A., Saddler, J.N., 1998. Techno-economic evaluations of a generic wood-to-ethanol process: effect of increased cellulose yields and enzyme recycle. Bioresour. Technol. 63(1), 7-12.

[44] Griffin, W.M., Saville, B.A., MacLean H.L., 2016. Ethanol use in the United States: status, threats and the potential future. Global Bioethanol. Elsevier. 34-62.

[45] Hahn-Hägerdal, B., Galbe, M., Gorwa-Grauslund, M.F., Lidén, G. Zacchi, G., 2006. Bio-ethanol-the fuel of tomorrow from the residues of today. Trends Biotechnol. 24(12), 549-556.

[46] Heringer, N.B., 2016. Minimizing ethanol concentration in organosolv pretreatment for the saccharifcation of Loblolly Pine.

[47] Hubbe, M.A., 2015. Lignin as a value-added byproduct to improve the economics of lignoethanol?. Biofuel Res. J. 2(4), 295.

[48] Idígoras, G., 2016. Análisis Tecnológicos Y Prospectivos Sectoriales. Prospectiva tecnológica al 2025 del complejo foresto-industrial Ministerio de Ciencia, Tecnología e Innovación Productiva.

[49] Inoue, H., Fujimoto, S., Sakaki, T., 2016. Two-step hot-compressed water treatment of douglas fir for efficient total sugar recovery by enzymatic hydrolysis. BioResources. 11(2), 5124-5137.

[50] Inoue, H., Yano, S., Endo, T., Sakaki, T., Sawayama, S., 2008. Combining hot-compressed water and ball milling pretreatments to improve the efficiency of the enzymatic hydrolysis of eucalyptus. Biotechnol. Biofuels. 1(1), 2.

[51] Jain, A., Bridges, W.C., 2016. Comparison of chemical treatment methods for loblolly pine to utilize as enzyme hydrolyzate feedstock. Biomass Bioenergy. 94, 130-145. 
[52] Janssen, R., Rutz, D.D., 2011. Sustainability of biofuels in Latin America: risks and opportunities. Energy Policy. 39(10), 5717-5725.

[53] Kang, Q., Appels, L., Tan, T., Dewil, R., 2014. Bioethanol from lignocellulosic biomass: current findings determine research priorities. Sci. World J. 2014, 1-13.

[54] Karunanithy, C., Muthukumarappan, K., Gibbons, W.R., 2012. Extrusion pretreatment of pine wood chips. Appl. Biochem. Biotechnol. 167(1), 81 99.

[55] Kazi, F.K., Fortman, J., Anex, R., Kothandaraman, G., Hsu, D., Aden, A., Dutta, A., 2010. Techno-economic analysis of biochemical scenarios for production of cellulosic ethanol. Technical Report NREL/TP-6A246588. National Renew. Energy Lab. (NREL).

[56] Kemp, I., 2007. Pinch Analysis and Process Integration: a User Guide on Process Integration for the Efficient Use of Energy, 2nd ed. Elsevier Ltd, Butterworth-Heinemann.

[57] Killmann, W., 2006. Tendencias y perspectivas del sector forestal en América Latina y el Caribe. FAO, Roma (Italia)

[58] Kim, K.H., Hong, J., 2001. Supercritical $\mathrm{CO}_{2}$ pretreatment of lignocellulose enhances enzymatic cellulose hydrolysis. Bioresour. Technol. 77(2), 139-144.

[59] Kline, K.L., Oladosu, G.A., Wolfe, A.K., Perlack, R.D., Dale, V.H., McMahon, M., 2008. Biofuel feedstock assessment for selected countries: to support the doe study of worldwide potential to produce biofuels with a focus on U.S. imports. Oak Ridge Nat. Lab. 243.

[60] Kruyeniski, J., Ferreira, P.J., Carvalho, M.G., Felissia, F.E., Area, M.C., 2016a. Physical and chemical characteristics of pretreated pine sawdust and its enzymatic hydrolysis, in: Iberoamerican Congress on Pulp and Paper Research (CIADICYP). Helsinki, Finland.

[61] Kruyeniski, J., Chamorro, E., Arismendy, A.M., Felissia, F.E., Area, M.C., 2016b. Evaluating fermentability of hydrolyzates of pretreated pine sawdust, in: Workshop on Insights and Strategies Towards a Bio-Based Economy. Montevideo, Uruguay.

[62] Laaksonen-Craig, S., 2008. The determinants of foreign direct investments in latin american forestry and forest industry. J. Sustain For. 27(1-2), 172-188.

[63] Lemos, P., Mesquita, F.C., 2016. Future of global bioethanol: an appraisal of results, risk and uncertainties. Global Bioethanol. Elsevier. 221-237.

[64] Lienqueo, M.E., Ravanal, M.C., Pezoa-Conte, R., Cortínez, V., Martínez, L., Niklitschek, T., Salazar, O., Carmona, R., García, A., Hyvärinen, S., Mäki-Arvela, P., 2016. Second generation bioethanol from Eucalyptus globulus Labill and Nothofagus pumilio: ionic liquid pretreatment boosts the yields. Ind. Crops Prod. 80, 148-155

[65] Li, H.Y., Chen, X., Wang, C.Z., Sun, S.N., Sun, R.C., 2016. Evaluation of the two-step treatment with ionic liquids and alkali for enhancing enzymatic hydrolysis of Eucalyptus: chemical and anatomical changes. Biotechnol. Biofuels. 9(1), 166.

[66] Li, M., Tu, M., Cao, D., Bass, P., Adhikari, S., 2013. Distinct roles of residual xylan and lignin in limiting enzymatic hydrolysis of organosolv pretreated loblolly pine and sweetgum. J. Agric. Food Chem. 61(3), 646654.

[67] Lynd, L.R., Van Zyl, W.H., McBride, J.E., Laser, M., 2005. Consolidated bioprocessing of cellulosic biomass: an update. Curr. Opin. Biotechnol. $16(5), 577-583$

[68] Martín-Sampedro, R., Eugenio, M.E., García, J.C., Lopez, F., Villar, J.C., Diaz, M.J., 2012. Steam explosion and enzymatic pre-treatments as an approach to improve the enzymatic hydrolysis of Eucalyptus globulus. Biomass Bioenergy. 42, 97-106.

[69] Mattos, B.D., Lourençon, T.V., Gatto, D.A., Serrano, L., Labidi, J., 2016. Chemical characterization of wood and extractives of fast-growing Schizolobium parahyba and Pinus taeda. Wood Mater. Sci. Eng. 11(4), 209-216.

[70] McIntosh, S., Vancov, T., Palmer, J., Spain, M., 2012. Ethanol production from Eucalyptus plantation thinnings. Bioresour. Technol. 110, 264-272.

[71] McIntosh, S., Zhang, Z., Palmer, J., Wong, H.H., Doherty, W.O., Vancov, T., 2016. Pilot-scale cellulosic ethanol production using eucalyptus biomass pre-treated by dilute acid and steam explosion. Biofuels, Bioprod. Biorefin. 10(4), 346-358.

[72] Meier, E., 2016. Wood!: Identifying and Using Hundreds of Woods Worldwide. Wood Database.
[73] Melin, K., Hurme, M., 2011. Lignocellulosic biorefinery economic evaluation. Cellul. Chem. Technol. 45(7-8), 443-454.

[74] Monrroy, M., Renán García, J.O.S.É., Teixeira Mendonca, R., Baeza, J., Freer, J., 2012. Kraft pulping of Eucalyptus globulus as a pretreatment for bioethanol production by simultaneous saccharification and fermentation. J. Chil. Chem. Soc. 57(2), 1113 1117.

[75] Morales, M., Pielhop, T., Saliba, P., Hungerbühler, K., Rudolf von Rohr, P., Papadokonstantakis, S., 2017. Sustainability assessment of glucose production technologies from highly recalcitrant softwood including scavengers. Biofuels, Bioprod. Biorefin. 11(3), 441-453.

[76] Morales Olmos, V., Siry, J.P., 2009. Economic impact evaluation of Uruguay forest sector development policy. J. For. 107(2), 63-68.

[77] Muktham, R., Bhargava, S.K., Bankupalli, S., Ball, A.S., 2016. A review on 1 st and 2 nd generation bioethanol production-recent progress. J. Sust. Bioenergy Syst. 6(3), 72-92.

[78] Naik, S.N., Goud, V.V., Rout, P.K., Dalai, A.K., 2010. Production of first and second generation biofuels: a comprehensive review. Renew. Sust. Energy Rev. 14(2), 578-597.

[79] Pan, X., Arato, C., Gilkes, N., Gregg, D., Mabee, W., Pye, K., Xiao, Z., Zhang, X., Saddler, J., 2005. Biorefining of softwoods using ethanol organosolv pulping: preliminary evaluation of process streams for manufacture of fuel-grade ethanol and co-products. Biotechnol. Bioeng. 90(4), 473-481.

[80] Pan, X., Xie, D., Yu, R.W., Saddler, J.N., 2008. The bioconversion of mountain pine beetle-killed lodgepole pine to fuel ethanol using the organosolv process. Biotechnol. Bioeng. 101(1), 39-48

[81] Park, J.Y., Kang, M., Kim, J.S., Lee, J.P., Choi, W.I., Lee, J.S., 2012 Enhancement of enzymatic digestibility of Eucalyptus grandis pretreated by $\mathrm{NaOH}$ catalyzed steam explosion. Bioresour. Technol. 123, 707-712.

[82] Park, N., Kim, H.Y., Koo, B.W., Yeo, H., Choi, I.G., 2010 Organosolv pretreatment with various catalysts for enhancing enzymatic hydrolysis of pitch pine (Pinus rigida). Bioresour. Technol. 101(18), 7046-7053.

[83] Pinto, P.C.R., Costa, C.E., Rodrigues, A.E., 2013. Oxidation of lignin from Eucalyptus globulus pulping liquors to produce syringaldehyde and vanillin. Ind. Eng. Chem. Res. 52(12), 4421-4428.

[84] PROBIOMASA, 2012. Utilización de biomasa con fines energéticos en la Provincia de Misiones, Reunión de presentación. Proyecto para la promoción de la energía derivada de biomasa PROBIOMASA. Consejo ejecutivo y consultivo de energías renovables, biocombustibles e hidrógeno.

[85] Rajagopalan, N., Venditti, R., Kelley, S., Daystar, J., 2017. Multiattribute uncertainty analysis of the life cycle of lignocellulosic feedstock for biofuel production. Biofuels, Bioprod. Biorefin. 11(2), $269-280$

[86] Ramos, L.P., Carpes, S.T., Silva, F.T., Ganter, J.L.M., 2000 Comparison of the susceptibility of two hardwood species, Mimosa scabrella Benth and Eucalyptus viminalis Labill, to steam explosion and enzymatic hydrolysis. Braz. Arch. biol. technol. 43(2), 195-206.

[87] Rangel, J., Hornus, M., Felissia, F.E., Area, M.C., 2016 Hydrothermal treatment of eucalyptus sawdust for a forest biorefinery. Cellul. Chem. Technol. 50(5-6), 521-528.

[88] Reina, L., Resquin, F., 2011. Eucalyptus globulus chemical composition and its effect on Kraft pulping parameters.

[89] Reyes, P., Mendonça, R.T., Aguayo, M.G., Rodríguez, J., Vega, B. Fardim, P., 2013. Extraction and characterization of hemicelluloses from Pinus radiata and its feasibility for bioethanol production. Revista Árvore. 37(1), 175-180.

[90] Rico, A., Rencoret, J., del Río, J.C., Martínez, A.T., Gutiérrez, A. 2014. Pretreatment with laccase and a phenolic mediator degrades lignin and enhances saccharification of Eucalyptus feedstock. Biotechnol. Biofuels. 7(1), 6.

[91] Romaní, A., Garrote, G., Alonso, J.L., Parajó, J.C., 2010. Bioethanol production from hydrothermally pretreated Eucalyptus globulus wood. Bioresour. Technol. 101(22), 8706-8712.

[92] Romaní, A., Garrote, G., López, F., Parajó, J.C., 2011. Eucalyptus globulus wood fractionation by autohydrolysis and organosolv delignification. Bioresour. Technol. 102(10), 5896-904. 
[93] Romaní, A., Garrote, G., Parajó, J.C., 2012. Bioethanol production from autohydrolyzed Eucalyptus globulus by Simultaneous Saccharification and Fermentation operating at high solids loading. Fuel. 94, 305-312.

[94] Ruz, E., Hilbert, J., Carballo, S.M., Sundfeld, E., Coutinho, A., Perez, C., Mayeregger, M., Vazquez, D., Resquin, F., Ganduglia, F., 2014. Lignocellulosic biomass residues identification and selection in five countries of Latin America, as a feedstock for second generation ethanol production. Proceeding of RCN conference on Pan American Biofuel and Bioenergy Sustainability. Recife, Brazil.

[95] Salmén, L., Burgert, I., 2009. Cell wall features with regard to mechanical performance. A review COST action E35 2004-2008: wood machiningmicromechanics and fracture. Holzforschung. 63(2), 121-129.

[96] Sannigrahi, P., Miller, S.J., Ragauskas, A.J., 2010. Effects of organosolv pretreatment and enzymatic hydrolysis on cellulose structure and crystallinity in Loblolly pine. Carbohydr. Res. 345(7), 965-970.

[97] Sannigrahi, P., Ragauskas, A., Miller, S., 2008. Effects of two-stage dilute acid pretreatment on the structure and composition of lignin and cellulose in loblolly pine. Bioenergy Res. 1(3-4), 205-214

[98] Santos, R.B., Lee, J.M., Jameel, H., Chang, H.M., Lucia, L.A., 2012. Effects of hardwood structural and chemical characteristics on enzymatic hydrolysis for biofuel production. Bioresour. Technol. 110, 232-238.

[99] Saska, M., Ozer, E., 1995. Aqueous extraction of sugarcane bagasse hemicellulose and production of xylose syrup. Biotechnol. Bioeng. 45(6), 517-523.

[100]SENASA, 2014. Bosques argentinos, actividad forestal y economías regionales.

[101] Smeets, E., Faaij, A., Lewandowski, I., Turkenburg, W., 2007. A bottomup assessment and review of global bio-energy potentials to 2050. Prog. Energy Combust. Sci. 33(1), 56-106.

[102] Solomon, B.D., Bailis, R., 2014. Sustainable Development of Biofuels in Latin America and the Caribbean. Springer Science and Business Media. New York, pp. 1-26.

[103] Solomon, B.D., Barnes, J.R., Halvorsen, K.E., 2007. Grain and cellulosic ethanol: history, economics, and energy policy. Biomass Bioenergy. 31(6), 416-425

[104] Sorda, G., Banse, M., Kemfert, C., 2010. An overview of biofuel policies across the world. Energy Policy. 38(11), 6977-6988.

[105] Stephen, J.D., Mabee, W.E., Saddler, J.N., 2012. Will second-generation ethanol be able to compete with first-generation ethanol? opportunities for cost reduction. Biofuels, Bioprod. Biorefining. 6(2), 159-176.

[106] Stoffel, R., 2016. Doctoral dissertation: fraccionamiento de aserrín de pino destinado a una biorrefinería forestal. Universidad Nacional de La Plata, Facultad de Ingeniería.

[107] Stoffel, R.B., Felissia, F.E., Silva Curvelo, A.A.S., Gassa, L.M., Area, M.C., 2014. Optimization of sequential alkaline-acid fractionation of pine sawdust for a biorefinery. Ind. Crops Prod. 61, 160-168.

[108] Suckling, I.D., Jack, M.W., Lloyd, J.A., Murton, K.D., Newman, R.H., Stuthridge, T.R., Torr, K.M., Vaidya, A.A., 2017. A mild thermomechanical process for the enzymatic conversion of radiata pine into fermentable sugars and lignin. Biotechnol. Biofuels. 10(1), 61.

[109] Sun, S., Cao, X., Sun, S., Xu, F., Song, X., Sun, R.C., Jones, G.L., 2014. Improving the enzymatic hydrolysis of thermo-mechanical fiber from Eucalyptus urophylla by a combination of hydrothermal pretreatment and alkali fractionation. Biotechnol. Biofuels. 7(1), 116.

[110]Teramoto, Y., Tanaka, N., Lee, S.H., Endo, T., 2008. Pretreatment of eucalyptus wood chips for enzymatic saccharification using combined sulfuric acid-free ethanol cooking and ball milling. Biotechnol. Bioeng. 99(1), 75-85

[111]Testova, L., Vilonen, K., Pynnönen, H., Tenkanen, M., Sixta, H., 2009. Isolation of hemicelluloses from birch wood: distribution of wood components and preliminary trials in dehydration of hemicelluloses. Lenzinger Berichte. 87, 58-65.

[112]Tian, X., Rehmann, L., Xu, C.C., Fang, Z., 2016. Pretreatment of eastern white pine (Pinus strobes L.) for enzymatic hydrolysis and ethanol production by organic electrolyte solutions. ACS Sust. Chem. Eng. 4(5), 2822-2829

[113] Timilsina, G.R., Chisari, O.O., Romero, C.A., 2013. Economy-wide impacts of biofuels in Argentina. Energy Policy. 55, 636-647.

[114] Toppinen, A., Zhang, Y.Q., Geng, W., Laaksonen-Craig, S., Lähtinen, K., Li, N., Liu, C.I.M., Shen, Y., 2010. Changes in Global Markets for Forest
Products and Timberlands. International Union of Forestry Research Organizations (IUFRO). 25, 17-156

[115]Tu, M., Chandra, R.P., Saddler, J.N., 2007. Recycling cellulases during the hydrolysis of steam exploded and ethanol pretreated lodgepole pine. Biotechnol. Prog. 23(5), 1130-1137.

[116]Ugalde, L., Pérez, O., 2001. Mean annual volume increment of selected industrial forest plantation species by forest plantation thematic papers. Working Paper 1. Forest Resources Development Service, Forest Resources Division. FAO, Roma, Italia.

[117] Valenzuela, R., Priebe, X., Troncoso, E., Ortega, I., Parra, C., Freer J., 2016. Fiber modifications by organosolv catalyzed with $\mathrm{H}_{2} \mathrm{SO}_{4}$ improves the SSF of Pinus radiata. Ind. Crops Prod. 86, 79-86.

[118] Vallejos, M.E., Felissia, F.E., Area, M.C., 2017. Hydrotherma treatments applied to agro-and forest-industrial waste to produce high added-value compounds. BioResources. 12(1), 2058-2080.

[119] Vallejos, M.E., Zambon, M.D., Area, M.C., Curvelo, A.A., 2015 Low liquid-solid ratio fractionation of sugarcane bagasse by hot water autohydrolysis and organosolv delignification. Ind. Crops Prod. 65 349-353

[120] Vallejos, M.E., Zambon, M.D., Area, M.C., Curvelo, A.A., 2012 Low liquid-solid ratio (LSR) hot water pretreatment of sugarcane bagasse. Green Chem. 14(7), 1982.

[121] Van Eijck, J., Batidzirai, B., Faaij, A., 2014. Current and future economic performance of first and second generation biofuels in developing countries. Appl. Energy. 135, 115-141.

[122] van Gelder, J.W., German, L., Bailis, R., 2012. Biofuels investment in tropical forest-rich countries: implications for responsible finance. Sustainability Accounting, Manage. Policy J. 3(2), 134-160.

[123] Vazquez, G., Antorrena, G., Gonzalez, J., Freire, S., Crespo, I., 2000 The influence of acetosolv pulping conditions on the enzymatic hydrolysis of Eucalyptus pulps. Wood Sci. Technol. 34(4), 345-354.

[124]Von Sivers, M., Zacchi, G., 1995. A techno-economical comparison of three processes for the production of ethanol from pine. Bioresour. Technol. 51(1), 43-52.

[125]Walker, G.M., 2011. 125th anniversary review: fuel alcohol: current production and future challenges. J. Inst. Brew. 117(1), 3-22.

[126] Wei, W., Wu, S., Liu, L., 2012. Enzymatic saccharification of dilute acid pretreated eucalyptus chips for fermentable sugar production. Bioresour. Technol. 110, 302-307.

[127]Wingren, A., Galbe, M., Zacchi, G., 2008. Techno-economic evaluation of producing ethanol from softwood: comparison of SSF and SHF and identification of bottlenecks. Biotechnol. Prog. 19(4), 1109-1117.

[128]Wu, S., Chang, H., Phillips, R., Jameel, H., 2014. Techno-economic analysis of the optimum softwood lignin content for the production of bioethanol in a repurposed kraft mill. BioResources. 9(4), 6817-6830.

[129]Zabed, H., Sahu, J.N., Suely, A., Boyce, A.N., Faruq, G., 2017 Bioethanol production from renewable sources: current perspectives and technological progress. Renew. Sust. Energy Rev. 71, 475-501.

[130]Zaman, K., Awan, U., Islam, T., Paidi, R., Hassan, A., Abdullah, A. 2016. Econometric applications for measuring the environmenta impacts of biofuel production in the panel of worlds' largest region. Int. J. Hydrogen Energy. 41(7), 4305-4325.

[131]Zhu, J.Y., Pan, X.J., 2010. Woody biomass pretreatment for cellulosic ethanol production: technology and energy consumption evaluation. Bioresour. Technol. 101(13), 4992-5002.

[132]Zhu, J.Y., Pan, X.J., Wang, G.S., Gleisner, R., 2009. Sulfite pretreatment (SPORL) for robust enzymatic saccharification of spruce and red pine. Bioresour. Technol. 100(8), 2411-2418.

[133]Zhu, J.Y., Pan, X., Zalesny, R.S., 2010. Pretreatment of woody biomass for biofuel production: energy efficiency, technologies, and recalcitrance. Appl. Microbiol. Biotechnol. 87(3), 847-857. 